Hydrology and Earth System Sciences, 5(3), 391-405 (2001) (C) EGS

\title{
Sulphur and nitrogen fluxes and budgets in the Bohemian Forest and Tatra Mountains during the Industrial Revolution (1850-2000)
}

\author{
Jirí Kopácek ${ }^{1}$, Josef Veselý ${ }^{2}$ and Evzen Stuchlík ${ }^{3)}$ \\ ${ }^{1}$ Hydrobiological Institute, AS CR, and Faculty of Biological Sciences, USB, Na Sádkách 7, 37005 Ceské Budejovice, Czech Republic \\ ${ }^{2}$ Czech Geological Survey,Geologická 6, 15200 Praha 5 \\ ${ }^{3}$ Department of Hydrobiology, Charles University, Vinicná 7, 12044 Praha 2, Czech Republic
}

Email for corresponding author: jkopacek@hbu.cas.cz

\begin{abstract}
Major fluxes of sulphur and dissolved inorganic nitrogen were estimated in Central European mountain ecosystems of the Bohemian Forest (forest lakes) and Tatra Mountains (alpine lakes) over the industrial period. Sulphur outputs from these ecosystems were comparable to inputs during a period of relatively stable atmospheric deposition (10-35 mmol m$\left.{ }^{-2} \mathrm{yr}^{-1}\right)$ around the 1930s. Atmospheric inputs of sulphur increased by three- to four-fold between the 1950s and 1980s to $\sim 140$ and $\sim 60 \mathrm{mmol} \mathrm{m}^{-2} \mathrm{yr}^{-1}$ in the Bohemian Forest and Tatra Mountains, respectively. Sulphur outputs were lower than inputs due to accumulation in soils, which was higher in forest soils than in the sparser alpine soils and represented 0.8-1.6 and 0.2-0.3 mol m², respectively, for the whole 1930-2000 period. In the 1990s, atmospheric inputs of sulphur decreased $80 \%$ and $50 \%$ in the Bohemian Forest and Tatra Mountains, respectively, and sulphur outputs exceeded inputs. Catchment soils became pronounced sources of sulphur with output fluxes averaging between 15 and $31 \mathrm{mmol} \mathrm{m}^{-2} \mathrm{yr}^{-1}$. Higher sulphur accumulation in the forest soils has delayed (by several decades) recovery of forest lakes from acidification compared to alpine lakes. Estimated deposition of dissolved inorganic nitrogen was 53-75 mmol m${ }^{-2} \mathrm{yr}^{-1}$ in the Bohemian Forest and 35-45 $\mathrm{mmol} \mathrm{m}^{-2} \mathrm{yr}^{-1}$ in the Tatra Mountains in the 18801950 period, i.e. below the empirically derived threshold of $\sim 70 \mathrm{mmol} \mathrm{m}^{-2} \mathrm{yr}^{-1}$, above which nitrogen leaching often occurs. Dissolved inorganic nitrogen was efficiently retained in the ecosystems and nitrate export was negligible (0-7 $\left.\mathrm{mmol} \mathrm{m}^{-2} \mathrm{yr}^{-1}\right)$. By the $1980 \mathrm{~s}$, nitrogen deposition increased to $\sim 160$ and $\sim 80 \mathrm{mmol} \mathrm{m}^{-2} \mathrm{yr}^{-1}$ in the Bohemian Forest and Tatra Mountains, respectively, and nitrogen output increased to 120 and $60 \mathrm{mmol} \mathrm{m}^{-2} \mathrm{yr}^{-1}$. Moreover, assimilation of nitrogen in soils declined from $\sim 40$ to $10-20 \mathrm{mmol} \mathrm{m}^{-2} \mathrm{yr}^{-1}$ in the alpine soils and even more in the Bohemian Forest, where one of the catchments has even become a net source of nitrogen. In the 1990s, nitrogen deposition decreased by $\sim 30 \%$ and DIN output decreased to $<70$ and $35 \mathrm{mmol} \mathrm{m}^{-2} \mathrm{yr}^{-1}$ in the Bohemian Forest and Tatra Mountains, respectively. New steady-state conditions, with negligible nitrogen export, could be reached in future but at lower nitrogen depositions than in the 1930s.
\end{abstract}

Keywords: emission, deposition, acidification, nitrogen-saturation, recovery, sulphate, nitrate, ammonium, mountain lakes

\section{Introduction}

Many European and North American regions have recently shown a widespread reversal in surface water acidification due to declining deposition of acidifying compounds (e.g. Stoddard et al., 1999; Evans et al., 2001). The extent and timing of increased acid neutralising capacity (ANC) and $\mathrm{pH}$ depends, however, not only on the reduction in emission/ deposition rate of sulphur (S) and nitrogen (N) compounds but also on the way that soils and vegetation respond to their reductions (e.g. Wright and Hauhs, 1991; Alewell et al., 2000). Among them, sulphate $\left(\mathrm{SO}_{4}\right)$ desorption, organic S cycling in soils (Novák et al., 1996; Torssander and Mörth, 1998; Prechtel et al., 2001) and factors affecting N cycling in catchments (e.g. Dise and Wright, 1995; Aber et al., 1998) are important. Published trends in water chemistry provide the "only" information on changes in composition relative to changing atmospheric deposition. Studies of element fluxes within the whole ecosystem help to understand the processes contributing to this change.

With the exception of "roof" experiments (e.g. Wright $e t$ al., 1993; Hultberg et al., 1998; Gundersen et al., 1998a), the greatest reduction in deposition of acidifying compounds has occurred in Central Europe. This large whole-ecosystem "experiment" has been based on $\sim 80 \%$ and $\sim 30 \%$ reduction in $\mathrm{S}$ and $\mathrm{N}$ emissions, respectively, in the area of Germany, Poland, the Czech Republic and Slovakia during the 1990s (Kopácek et al., 2001). Parallel decreases in deposition rates of $\mathrm{SO}_{4}$, nitrate $\left(\mathrm{NO}_{3}\right)$, and ammonium $\left(\mathrm{NH}_{4}\right)$ have resulted in relatively rapid improvement in water quality in acidified 
mountain lakes in this area (e.g. Kopácek et al., 1998; Veselý et al., 1998).

In this paper major fluxes of $\mathrm{S}$ and $\mathrm{N}$ compounds in two Central European mountain areas (Bohemian Forest and Tatra Mountains) are estimated for the whole industrial period. First, historical (1850-2000) emission rates of S and $\mathrm{N}$ in the area of the Czech Republic and Slovakia are reconstructed. Second, historical trends in $\mathrm{S}$ and $\mathrm{N}$ deposition in the mountains are estimated using relationships between emission rate and measured deposition. Third, S and $\mathrm{N}$ outputs from catchment-lake ecosystems are estimated using historical and recent water chemistry records. Finally, the input-output fluxes are used to estimate possible changes in soil storage of S and N over the 1930-2000 period.

\section{Methods}

\section{SITE DESCRIPTION, WATER AND SOIL CHEMISTRY}

The areas of the Bohemian Forest (BF) and Tatra Mountains (TM) are situated at $13^{\circ}-14^{\circ} \mathrm{E}, 49^{\circ} \mathrm{N}$ and $20^{\circ} 10^{\prime} \mathrm{E}, 49^{\circ} 10^{\prime}$ $\mathrm{N}$, respectively. Two lakes (Cerné, $\mathrm{CN}$, and Certovo, CT) were studied in BF (Table 1). These lakes are situated in steep, forested catchments, planted predominantly with Norway spruce and sparse beech. Soils are mostly acidic podzols in different stages of development and/or cambisols (average depth of $\sim 0.6 \mathrm{~m}$ ) with cation exchange capacity between 16 and $82 \mathrm{eq} \mathrm{m}^{-2}$ (average of $23 \mathrm{eq} \mathrm{m}^{-2}$ ), base saturation of $10-13 \%$ and $\mathrm{pH}$ (water extracts; $\mathrm{H}_{2} \mathrm{O}$ ) of mineral B horizons of 3.7-4.6 (Kopácek, unpubl. data).

Table 1. Major morphological and chemical parameters of the Bohemian Forest (BF) and Tatra Mountains (TM) catchmentlake ecosystems. Chemical composition of lake water refers to September-October 2000 (Kopácek and Stuchlík, unpubl. data). BC, base cations (sum of $\mathrm{Ca}, \mathrm{Mg}, \mathrm{Na}$ and $\mathrm{K}$ ); DOC and DON, dissolved organic carbon and nitrogen, respectively.

\begin{tabular}{|c|c|c|c|c|c|c|}
\hline Lake & & Cerné & Certovo & Wielki Staw & $\begin{array}{l}\text { Morskie } \\
\text { Oko }\end{array}$ & $\begin{array}{l}\text { Vyšné } \\
\text { Wahlenbergovo }\end{array}$ \\
\hline Code & & $\mathrm{CN}$ & $\mathrm{CT}$ & WS & MO & VW \\
\hline Location & & $\mathrm{BF}$ & $\mathrm{BF}$ & $\mathrm{TM}$ & $\mathrm{TM}$ & $\mathrm{TM}$ \\
\hline Max. depth & $\mathrm{m}$ & 40 & 36 & 79.3 & 50.8 & 20 \\
\hline Area & ha & 18.4 & 10.3 & 34.4 & 34.9 & 5.2 \\
\hline Volume & $10^{3} \mathrm{~m}^{3}$ & 2880 & 1850 & 12970 & 9940 & 421 \\
\hline Catchment & ha & 129 & 86 & 493 & 653 & 32 \\
\hline Min. altitude & m a.s.l. & 1008 & 1028 & 1665 & 1395 & 2145 \\
\hline Max. altitude & m a.s.l. & 1343 & 1343 & 2300 & 2499 & 2405 \\
\hline Soils ${ }^{1)}$ & $\mathrm{kg} \mathrm{m}^{-2}$ & 165 & 240 & 82 & 66 & 20 \\
\hline Vegetation & $\begin{array}{l}\text { in } \% \text { of } \\
\text { area }\end{array}$ & $\begin{array}{l}\text { 90-forest } \\
\text { (Norway } \\
\text { spruce) }\end{array}$ & $\begin{array}{l}\text { 90-forest } \\
\text { (Norway } \\
\text { spruce) }\end{array}$ & $\begin{array}{l}\text { 45-meadows } \\
15 \text {-dwarf pine } \\
25 \text {-moraine } \\
15 \text {-bare rocks }\end{array}$ & $\begin{array}{l}\text { 20-meadows } \\
\text { 30-dwarf pine } \\
\text { and/or forest } \\
\text { 15-moraine } \\
\text { 40-bare rocks }\end{array}$ & $\begin{array}{l}\text { 11-meadows } \\
\text { 46-moraine } \\
\text { 43-bare rocks }\end{array}$ \\
\hline $\mathrm{pH}$ & & 4.9 & 4.6 & 6.7 & 6.9 & 6.3 \\
\hline $\mathrm{HCO}_{3}^{-}$ & $\mu$ eq $1^{-1}$ & 0 & 0 & 73 & 130 & 29 \\
\hline $\mathrm{SO}_{4}^{2-{ }^{3}}$ & $\mu$ eq $1^{-1}$ & 87 & 91 & 44 & 56 & 31 \\
\hline $\mathrm{NO}_{3}^{-}$ & $\mu$ eq $1^{-1}$ & 62 & 35 & 19 & 24 & 26 \\
\hline $\mathrm{Cl}^{-}$ & $\mu$ eq $1^{-1}$ & 19 & 18 & 3 & 4 & 5 \\
\hline $\mathrm{NH}_{4}^{+}$ & $\mu$ eq $1^{-1}$ & 1 & 2 & 1 & 1 & 1 \\
\hline $\mathrm{BC}^{4}$ & $\mu$ eq $1^{-1}$ & 141 & 85 & 145 & 217 & 95 \\
\hline $\mathrm{Al}_{\mathrm{i}}^{\mathrm{n+}}$ & $\mu$ eq $1^{-1}$ & 20 & 33 & $<0.5$ & $<0.5$ & $<0.5$ \\
\hline DOC & $\mu \mathrm{mol} \mathrm{l}^{-1}$ & 83 & 233 & 34 & 39 & 13 \\
\hline DON & $\mu \mathrm{mol} 1^{-1}$ & 9 & 13 & 7 & 6 & 5 \\
\hline
\end{tabular}

${ }^{1)}$ Average bulk density of soil $\left(<2 \mathrm{~mm}, 105^{\circ} \mathrm{C}\right.$ dried), calculated as area weighted mean including moraine and bare rocks (Kopácek, unpubl. data). 
Bedrock is formed primarily of mica-schists (muscovitic gneiss), with small quartzite intrusions (Veselý, 1994).

Despite their relatively rapid reversal from acidification and N saturation (Kopácek et al., 1998; Veselý et al., 1998), both lakes are still acidic, with elevated concentrations of aluminium (Al) (Table 1). Trends in concentrations of $\mathrm{SO}_{4}$, $\mathrm{NO}_{3}$, and $\mathrm{NH}_{4}$ in $\mathrm{CN}$ and $\mathrm{CT}$ come from Jírovec and Jírovcová (1937), Veselý et al. (1998), Procházková and Blažka (1999), and Stuchlík and Kopácek (unpubl. data). The historical data used before 1984 has been found to be reasonably reliable (Veselý and Majer, 1992; Procházková and Blažka, 1999). Background (pre-acidification) concentrations of $\mathrm{SO}_{4}$ in $\mathrm{CN}$ and $\mathrm{CT}$ have been estimated to be $\sim 16$ and $\sim 20 \mu \mathrm{mol} \mathrm{l}^{-1}$, respectively, by Veselý and Majer (1992).

Three lakes (Wielki Staw, WS; Morskie Oko, MO, and Vyšné Wahlenbergovo, VW) were studied in TM. WS and VW are situated in the alpine zone, while MO is below the local tree line with $>80 \%$ of catchment in the alpine zone. Dry alpine meadows and sparse dwarf pine represent the dominant vegetation in these catchments (Table 1). Bedrock is mostly composed of granodiorite. Soils above the tree line are undeveloped alpine soils (lithosol, ranker) with average depth of $\sim 0.5 \mathrm{~m}$, mean cation exchange capacity of $12 \mathrm{eq} \mathrm{m}^{-2}$, base saturation of $11 \%$, and $\mathrm{pH}\left(\mathrm{H}_{2} \mathrm{O}\right)$ of mineral horizons of 4.7 (Kopácek, unpubl. data). The carbonate buffering system of WS and MO was not depleted during acidification and has been recently recovered in VW (Kopácek et al., 1998). Trends in concentrations of $\mathrm{SO}_{4}$ and $\mathrm{NO}_{3}$ in WS, MO, and VW come from Stangenberg (1938), Bombówna, (1965), Henriksen et al. (1992), Bombówna and Wojtan (1996), and Kopácek and Stuchlík (1994 and unpubl. data).

Concentrations of dissolved organic nitrogen (DON) in $\mathrm{BF}$ and TM precipitation and total DON in lakes were determined over the 1997-2000 and 1986-2000 period, respectively, by Kjeldahl combustion according to Procházková (1960). Concentrations of organic carbon (C) and total $\mathrm{N}$ in soil samples were analysed by $\mathrm{CN}$ analyser (NC 2100, ThermoQuest, Italy). Total S was determined after mineralisation and precipitation as $\mathrm{BaSO}_{4}$, and water extractable $\mathrm{SO}_{4}-\mathrm{S}$ was determined according to Alewell (1998). Average areal amount of these elements $\left(\mathrm{mol} \mathrm{m}^{-2}\right)$ was calculated from their average contents in soil $\left(\mathrm{mol} \mathrm{kg}{ }^{-1}\right)$ and bulk density of soil $\left(\mathrm{kg} \mathrm{m}^{-2}\right)$. In TM catchments with large areas of bare rock and moraine, the average areal amounts of elements were calculated as area weighted means. These hypothetical values represent a situation where soils were uniformly distributed over the whole catchment (Table 1). Average bulk densities of soil used in this calculation were 122 and $33 \mathrm{~kg} \mathrm{~m}^{-2}$ for alpine meadows and moraine, respectively (Kopácek, unpubl. data).

\section{EMISSION AND DEPOSITION RATES OF SULPHUR} AND NITROGEN

The historical Czech and Slovak (CS) and Central European (Germany, Poland, Czech Republic, and Slovakia) emission trends for sulphur dioxide $\left(\mathrm{SO}_{2}\right)$, nitrogen oxides $\left(\mathrm{NO}_{\mathrm{x}}\right)$, and ammonia $\left(\mathrm{NH}_{3}\right)$ were obtained similarly to Kopácek et al. (1998) but for a longer period. Details are given in Appendix 1.

Long-term trends in throughfall and bulk deposition of $\mathrm{SO}_{4}, \mathrm{NH}_{4}$ and $\mathrm{NO}_{3}$ in the $\mathrm{BF}$ and $\mathrm{TM}$ were estimated using their relationships with long-term trends in deposition of $\mathrm{S}$ and $\mathrm{N}$ compounds in the Czech Republic and northern Slovakia (Chopok). These estimations were based on ratios between the measured depositions in BF and wet-only deposition in the Czech Republic, and on ratios between the measured bulk depositions in TM and bulk depositions in northern Slovakia (Appendix 2). Long-term trends in deposition of $\mathrm{SO}_{4}, \mathrm{NH}_{4}$, and $\mathrm{NO}_{3}$ were estimated from relationships between measured deposition and the respective CS emissions of $\mathrm{SO}_{2}, \mathrm{NH}_{3}$ and $\mathrm{NO}_{\mathrm{x}}$. Details on data sources, calculation, significance of relationships and uncertainty are given in Appendix 2.

\section{SULPHUR AND NITROGEN FLUXES}

Mass balance of $\mathrm{S}$ and $\mathrm{N}$ in catchment-lake ecosystems was estimated using Eqn. (1):

$M_{\text {OUTPUT }}=M_{\text {INPUT }}-R_{\text {SOIL }}-R_{\text {LAKE }}-\Delta M_{\text {LAKE }}$

where $M_{\text {INPUT }}$ and $M_{\text {OUTPUT }}$ are S or N input and output to/ from the catchment-lake ecosystem, respectively. $R_{\text {SOIL }}$ and $R_{L A K E}$ are net mass retention (or production when negative) of $\mathrm{S}$ or $\mathrm{N}$ in the soil and lake, respectively. $\Delta M_{L A K E}$ is the change in storage of $\mathrm{S}$ or $\mathrm{N}$ in the lake and was obtained as the difference between its amount at the end and beginning of the mass budget period.

Atmospheric deposition was assumed to represent the dominant part of $M_{I N P U T}$ for both S and N. In this simplified approach S input from weathering was neglected. Similarly, assimilation of atmospheric $\mathrm{N}$ by terrestrial vegetation and $\mathrm{N}$ losses due to denitrification were assumed to be negligible in comparison to other $\mathrm{N}$ fluxes (Williams et al., 1995; Gundersen et al., 1998a) and to be roughly equal (Curtis $e t$ al., 1998). Sulphur input was calculated from estimated trends in throughfall and bulk deposition to the respective areas of forest and bare surface (including lake) in BF, and from estimated trend in bulk deposition of S in TM. Dry deposition of S in TM was only $~ 10 \%$ of total S deposition in 1996 (Lydersen et al., 1997) and was neglected. Input of $\mathrm{N}$ was the sum of estimated deposition of dissolved inorganic 
nitrogen $\left(\mathrm{DIN}=\mathrm{NO}_{3}-\mathrm{N}+\mathrm{NH}_{4}-\mathrm{N}\right.$; in throughfall and/or bulk) and bulk deposition of DON. The average bulk deposition of DON in the 1997-2000 period (13 and $7 \mathrm{mmol}$ $\mathrm{m}^{-2} \mathrm{yr}^{-1}$ in BF and TM, respectively) was used for a rough estimation of DON deposition over the 1930-2000 period assuming no important trend (Kopácek et al., 1997).

$M_{\text {OUTPUT }}$ of S and DIN from catchment-lake ecosystems were calculated from the measured concentrations of $\mathrm{SO}_{4}$, $\mathrm{NO}_{3}$ and $\mathrm{NH}_{4}$ in the lakes and the average annual water output. Mass balance over the 1930-2000 period was estimated assuming a linear trend between the measured data. The average lake water concentrations of total DON for the last decade were used to estimate cumulative DON flux from lakes over the whole 1930-2000 period, assuming negligible historical changes in DON concentrations in these phosphorus-limited water bodies (Kopácek et al., 1995).

The average annual water output from BF catchment-lake ecosystems was assumed to be $1.2 \mathrm{~m}^{3} \mathrm{~m}^{-2} \mathrm{yr}^{-1}$ and constant for the 1930-2000 period. This value was based on the average throughfall deposition to the lakes $(1387 \mathrm{~mm}$ over the 1991-2000 period), 15\% evaporation of throughfall (Kopácek et al., 2000a), and long-term (1961-2000) precipitation in BF. For TM lakes, the specific outflow was 1.42 and $1.57 \mathrm{~m}^{3} \mathrm{~m}^{-2} \mathrm{yr}^{-1}$ for the south (VW) and north (WS and MO) part of the mountains (Lajczak, 1996). Uncertainty associated with $\mathrm{S}$ or $\mathrm{N}$ output from ecosystems in individual years was roughly estimated as a coefficient of variation of the average level of precipitation $(< \pm 15 \%$ for $\mathrm{BF})$.

In-lake retention of $\mathrm{SO}_{4}$ and $\mathrm{NO}_{3}$ was calculated according to Kelly et al. (1987), when the original relationship between in-lake reduction in $\mathrm{SO}_{4}$ or $\mathrm{NO}_{3}$ concentrations and their loading was rearranged into the form:

$$
R_{L A K E}=L A\left(1+\frac{Q}{A S_{M}}\right)^{-1}
$$

where $L$ is areal $\mathrm{SO}_{4}$ or $\mathrm{NO}_{3}$ loading (terrestrial output and deposition to lake; $\left.\mathrm{mol} \mathrm{m} \mathrm{mr}^{-1}\right), A$ is lake area $\left(\mathrm{m}^{2}\right), Q$ discharge $\left(\mathrm{m}^{3} \mathrm{yr}^{-1}\right)$, and $S_{M}$ is mass transfer coefficient. $S_{M}$ was set here to the values 0.4 and $7.4 \mathrm{~m} \mathrm{yr}^{-1}$ for $\mathrm{SO}_{4}$ and $\mathrm{NO}_{3}$, respectively (Kelly et al., 1987). A lower $S_{M}\left(5 \mathrm{~m} \mathrm{yr}^{-1}\right)$ was used for $\mathrm{NO}_{3}$ in colder alpine lakes in TM (Curtis et $a l ., 1998)$. Finally, $R_{\text {SOIL }}$ was calculated by difference from Eqn. (1).

Major fluxes of $\mathrm{S}$ and $\mathrm{N}$ calculated from Eqns. (1) and (2) were compared to measured fluxes within CT catchmentlake ecosystem. This mass budget was based on regular sampling of throughfall, precipitation, all surface tributaries and outflow (calibrated weir) in two-week to four-week intervals during the 1998-2000 period (Kopácek et al., 2000a).

\section{Results and discussion}

\section{SULPHUR}

Trends in emission and deposition rates of sulphur

Emission rate of $\mathrm{SO}_{2}$ increased nearly linearly between 1850 and 1950 (from $\sim 18$ to $\sim 100 \mathrm{mmol} \mathrm{m}^{-2} \mathrm{yr}^{-1}$, respectively) in the area of the Czech Republic and Slovakia (Fig. 1A). Heavy industrial production in this area after World War II resulted in a sharp increase in energy consumption, primarily based on lignite combustion, and consequently in an extremely high annual increase in $\mathrm{SO}_{2}$ emissions $\left(\sim 10 \mathrm{mmol} \mathrm{m}^{-2} \mathrm{yr}^{-1}\right)$. Emissions of $\mathrm{SO}_{2}$ increased four-fold between 1950 and the middle 1980s, levelled off at 390 $\mathrm{mmol} \mathrm{m} \mathrm{yr}^{-1}$ in the first half of the 1980s, and then decreased sharply $\left(\sim 21 \mathrm{mmol} \mathrm{m}^{-2} \mathrm{yr}^{-1}\right)$ in the 1985-1999 period (Fig.1 A). In 1999, CS emissions of $\mathrm{SO}_{2}$ were similar to those in the 1930s. Large reduction in lignite combustion and sulphur emission controls were the primary reasons for these recent changes (Kopácek et al., 1997, 1998).

The long term trend in CS emissions of $\mathrm{SO}_{2}$ is similar to the Central European trend, except for the 1970s and 1980s (Fig. 1A), when CS emissions of $\mathrm{SO}_{2}$ increased more sharply, due to extremely high emission rates in the GermanPolish-Czech border area with numerous electric power plants, to a maximum $\mathrm{SO}_{2}$ emissions of $\sim 800 \mathrm{mmol} \mathrm{m}^{-2} \mathrm{yr}^{-1}$. Consequently, the decrease in $\mathrm{SO}_{2}$ emissions was more pronounced in CS ( $85 \%)$ than the Central European trend $(\sim 70 \%)$.

Deposition rates of $\mathrm{S}$ in the Czech Republic and northern Slovakia, which were estimated from the trend in CS emissions of $\mathrm{SO}_{2}$, are given in Fig. 1B. The estimated deposition agrees well $(\mathrm{P}<0.001)$ with measured deposition. Trends in estimated $\mathrm{S}$ deposition in BF and TM are given in Figs. 1C and 1D, respectively. Deposition was relatively stable in both areas in the first half of the $20^{\text {th }}$ century, rapidly increased between 1950 and 1980, and reached a maximum in the early 1980s. Estimated deposition maxima were $\sim 165$ and $\sim 50 \mathrm{mmol} \mathrm{m}^{-2} \mathrm{yr}^{-1}$ in BF (throughfall and bulk deposition, respectively) and $\sim 60 \mathrm{mmol} \mathrm{m}{ }^{-2} \mathrm{yr}^{-1}$ in $\mathrm{TM}$. Recent $\mathrm{S}$ deposition has been $\sim 80 \%$ lower than in the 1980 s in BF, being similar to the $1930 \mathrm{~s}$, and $~ 50 \%$ lower in TM, approaching levels from the late 1950s (Figs. 1C and D).

\section{Fluxes and mass budget of sulphur}

Comparison between S fluxes estimated from Eqns. (1) and (2) and measured by mass budget studies (Kopácek et al., 2000a; and unpubl. data) are given for CT catchment-lake ecosystem in Table 2 . There are only small differences between the results primarily due to different precipitation 

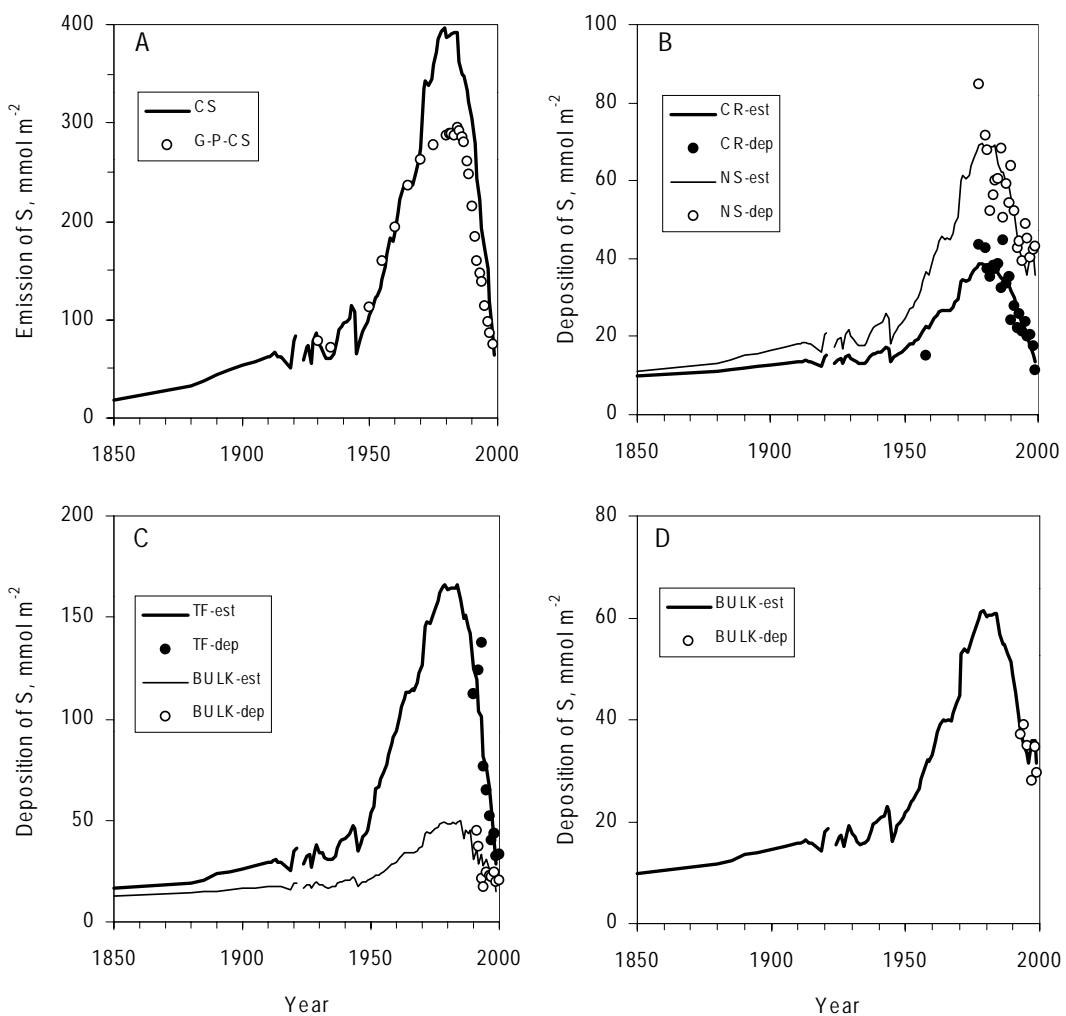

Fig. 1. Trends in emission and deposition rate of $\mathrm{S}:$ (A) Emissions of $\mathrm{SO}_{2}$ in the area of the Czech Republic and Slovakia (CS) and in Central Europe (Germany, Poland, Czech Republic and Slovakia, G-P-CS; Mylona, 1993; Berge, 1997). (B) Comparison between estimated and measured wet-only and bulk deposition of $\mathrm{SO}_{4}-\mathrm{S}$ in the Czech Republic $(\mathrm{CR})$ and northern Slovakia $(N S)$, respectively. (C) Comparison between estimated and measured throughfall (TF) and bulk (BULK) deposition of $\mathrm{SO}_{4}-\mathrm{S}$ in the Bohemian Forest. (D) Comparison between estimated and measured bulk (BULK) depositions of $\mathrm{SO}_{4}$-S in the Tatra Mountains. All data are based on annual means.

Table 2. Comparison between $\mathrm{S}$ fluxes in the Certovo catchment-lake ecosystem (CT), estimated from Eqns. (1) and (2) and measured (Kopácek et al. 2000a; and unpubl. data). Data are averages for 1998-2000 period; units are

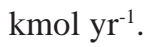

\begin{tabular}{lll}
\hline & estimated & measured \\
\hline$M_{\text {INPUT }}$ & 29.1 & 31.4 \\
$M_{\text {OUTPUT }}$ & 56.3 & 61.8 \\
$\Delta M_{\text {LAKE }}$ & $\mathrm{N}^{*}$ & -3.5 \\
$R_{\text {LAKE }}$ & 1.9 & 4.3 \\
$R_{\text {SOIL }}$ & 29.1 & 31.3 \\
${ }^{*} \mathrm{~N}$, neglected & & \\
\hline
\end{tabular}

levels (long-term average $v s$. real data) and the neglected change in S storage in the lake (dilution) in the more simple approach. Estimated data based on only sparse observations thus provide a reasonable estimation of the real $\mathrm{S}$ fluxes.

The upper part of Fig. 2 shows trends in estimated input and output fluxes of S in BF and TM catchment-lake ecosystems, while the lower part shows historical changes in ratios of S-output to S-input $\left(\mathrm{S}_{\text {out }}: \mathrm{S}_{\text {in }}\right)$. Sulphur input exceeded S output only slightly in the 1930s in both mountain areas and $S_{\text {out }}: S_{\text {in }}$ ratios were between 0.5 and 1 (Figs. 2C and D). This suggests low accumulation of $\mathrm{S}$ in soils and more or less steady state conditions. Under increasing $\mathrm{S}$ atmospheric input, however, the soil in both areas started to accumulate more S. Even in the early 1980s, $\mathrm{S}_{\text {out }}: \mathrm{S}_{\text {in }}$ ratios were $<1$ despite the highest deposition rate of $\mathrm{S}$. There were only small changes in the rate of $\mathrm{S}$ retention in forest soils between the 1960s and 1980s and they still continued to accumulate S (Fig. 2C). In contrast, alpine ecosystems of TM with thinner soil cover showed more pronounced signs of S-saturation (higher $\mathrm{S}_{\text {out }}: \mathrm{S}_{\text {in }}$ ratios), and after the decline in $\mathrm{S}$ deposition rate, $\mathrm{S}_{\text {out }}: \mathrm{S}_{\text {in }}$ ratios increased to $>1$ indicating that alpine ecosystems have become a source of S (Fig. 2D).

While both BF lakes, with comparable terrestrial characteristics and relatively abundant soils, have responded nearly uniformly and $\mathrm{S}_{\text {out }}: \mathrm{S}_{\text {in }}$ ratios remained high in the 1990s (Fig. 2C), responses of alpine TM lakes differed 

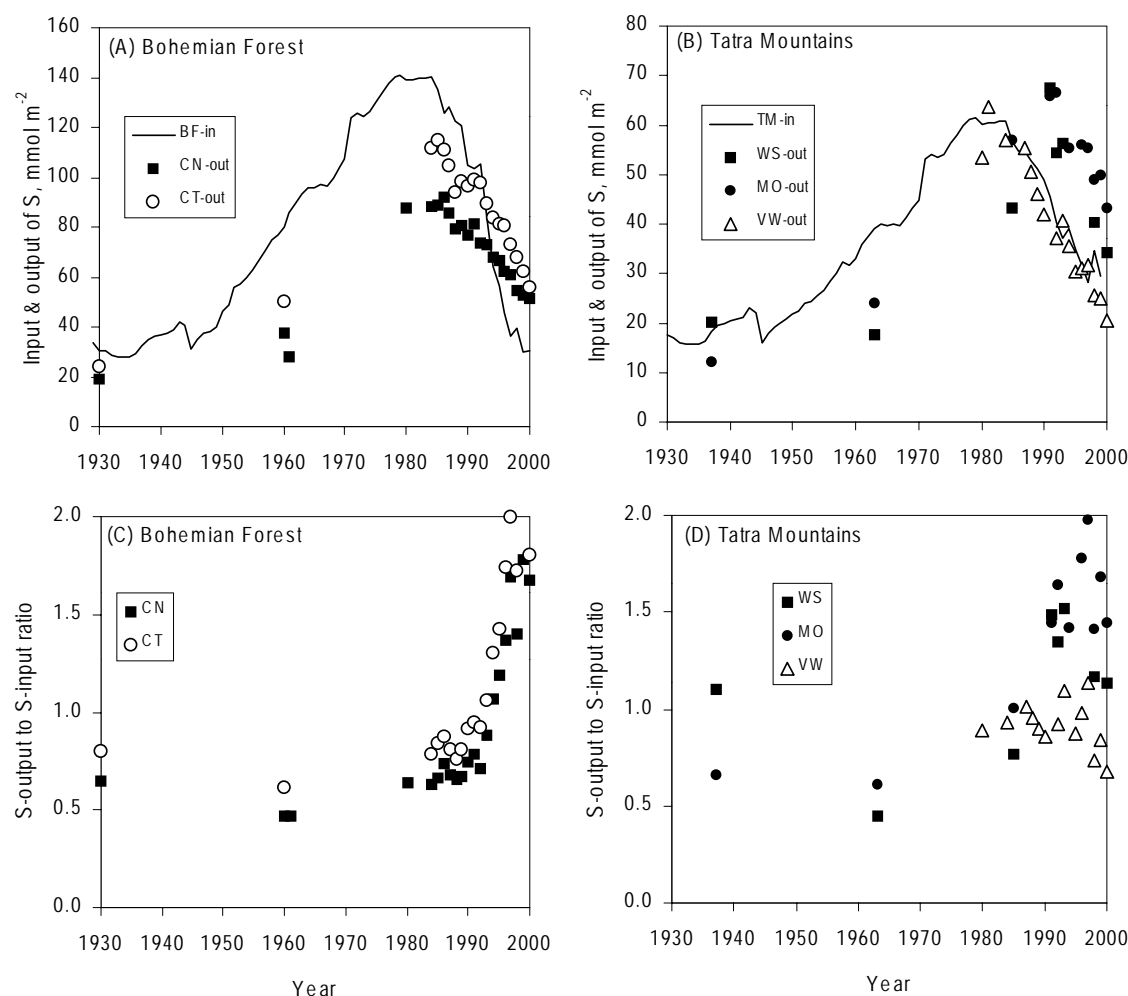

Fig. 2. Trends in S fluxes. Upper part: Comparison of S-input by atmospheric deposition in the Bohemian Forest (A) and Tatra Mountains $(B)$ to the S-output from catchment-lake ecosystems in the 1930-2000 period. Data on S output from CN and CT in 1930 are based on estimated background concentrations of $\mathrm{SO}_{4}$ in the lakes (Vesely and Majer, 1992). Lower part (C,D): Ratio of S-output to S-input. For lake codes see Table 1. All data are based on annual means.

according to the amount of soil (Figs. 2B and 2D). The smallest amount of soil is in the VW catchment where the low $\mathrm{S}$ retention capacity has resulted in relatively small changes in $\mathrm{S}_{\text {out }}: \mathrm{S}_{\text {in }}$ ratio (around 1) throughout the 19802000 period. Catchments of WS and MO lakes are covered with alpine meadows and have higher $\mathrm{S}$ retention capacity. Consequently, $\mathrm{S}_{\text {out }}: \mathrm{S}_{\text {in }}$ ratios increased to $>1$, reached their maxima in 1997 and have been decreasing since. This suggests that new steady state conditions in the soil S pool of alpine ecosystems can be reached relatively rapidly after reduction of $\mathrm{S}$ deposition, while this process may last substantially longer in forest ecosystems with deeper soils (e.g. Torssander and Mörth, 1998; Prechtel et al., 2001).

Cumulative atmospheric input of $\mathrm{S}$ over the whole period of the Industrial Revolution (1850-2000) was estimated to be $7.2 \mathrm{~mol} \mathrm{~m}^{-2}$ in BF and $3.5 \mathrm{~mol} \mathrm{~m}^{-2}$ in TM. Most of this $\mathrm{S}$ (70-80\%) was deposited in the 1930-2000 period (Table 3). Differences in S loading between the mountain areas were due mainly to differences in vegetation cover (trees $v s$. meadows). The forested area of BF had a higher specific surface area and, consequently, higher dry and occult deposition of S (throughfall and bulk deposition in Fig. 1C).

Cumulative S output from the forest sites was $67-82 \%$ of S deposition over the 1930-2000 period compared with S accumulation in soils of $15-29 \%$ (Table 3). Lower cumulative output and higher accumulation of $\mathrm{S}$ in soils was observed in $\mathrm{CN}$ catchment and resulted in higher total $\mathrm{S}$ in the soil (Table 3 ). The difference between $\mathrm{S}$ concentration in BF soils in the year 2000 and S accumulation over the 1930-2000 period was used to assess soil $\mathrm{S}$ content in the 1930s, i.e. during equilibrium between $\mathrm{S}$ input and output. These estimated steady-state pools of S in BF soils were similar in both $\mathrm{CT}$ and $\mathrm{CN}$ catchments $\left(1.6-1.8 \mathrm{~mol} \mathrm{~m}^{-2}\right)$.

The Bohemian Forest soils became a net source of $\mathrm{SO}_{4}-\mathrm{S}$ around 1993-1994 (Fig. 2), similar to the most damaged Central European region (the Ore Mountains; Novák et al., 2000) but were one order of magnitude lower. The average annual $\mathrm{SO}_{4}-\mathrm{S}$ leaching from $\mathrm{CN}$ and CT soils was 19 and $31 \mathrm{mmol} \mathrm{m}^{-2} \mathrm{yr}^{-1}$, respectively, over the 1994-2000 period. Based on the amount of water extractable $\mathrm{SO}_{4}-\mathrm{S}$ in $\mathrm{BF}$ soils in 2000 (Table 3), it is estimated that a similar level of leaching would only continue for the next five years. The soil $\mathrm{SO}_{4}-\mathrm{S}$ pool, however, is also supplied by mineralisation of organic S (Novák et al., 1996; Torssander and Mörth, 1998), as well as from sources of inorganic $\mathrm{S}$ (e.g. Al-SO complexes; Nordstrom, 1982). Therefore, if all of the $\mathrm{S}$ accumulated in BF soils over the 1930-2000 period was 
Table 3. Cumulative $\mathrm{S}$ budgets in the Bohemian Forest (CN and $\mathrm{CT}$ ) and Tatra (WS and MO) catchmentlake ecosystems. Numbers in brackets represent relevant year and/or period. For lake codes see Table 1. All units are $\mathrm{mol} \mathrm{m}^{-2}$. ND, not determined.

\begin{tabular}{|c|c|c|c|c|}
\hline & $C N$ & $C T$ & $W S$ & $M O$ \\
\hline Cumulative S deposition (1850-2000) & 7.1 & 7.2 & 3.5 & 3.5 \\
\hline Cumulative S deposition (1930-2000) & 5.5 & 5.6 & 2.6 & 2.6 \\
\hline Cumulative S output (1930-2000) & 3.7 & 4.6 & 2.3 & 2.3 \\
\hline In-lake retention of S $(1930-2000)^{1)}$ & 0.17 & 0.17 & 0.04 & 0.03 \\
\hline Change in S content in lake water $(1930-2000)^{1)}$ & 0.06 & 0.06 & 0.02 & 0.03 \\
\hline S retention in soil (1930-2000) & 1.6 & 0.8 & 0.3 & 0.2 \\
\hline Total S content in soil (2000) & 3.3 & 2.6 & 1.2 & 1.0 \\
\hline Water extractable $\mathrm{SO}_{4}-\mathrm{S}$ in soil (2000) & 0.101 & 0.117 & 0.014 & 0.011 \\
\hline Estimated total S content in soil $(1930)^{2)}$ & 1.6 & 1.8 & 0.9 & 0.8 \\
\hline \multicolumn{5}{|c|}{$\begin{array}{l}{ }^{1)} \text { In-lake } \mathrm{SO}_{4} \text { reduction and change in } \mathrm{SO}_{4} \text { content in lake water }(\mathrm{mol}) \text { were recalculated per total catchment } \\
\text { area }\left(\mathrm{mol} \mathrm{m}^{-2}\right) \text {. } \\
{ }^{2)} \text { Estimated total S content in soil in } 1930 \text { was the difference between the total S content in soil in } 2000 \text { and } \\
\text { the estimated S retention in soil over the } 1930-2000 \text { period. }\end{array}$} \\
\hline
\end{tabular}

available and could be transported at the present leaching rate, the process of $\mathrm{S}$ wash out would last about 26 years for CT and 84 years for CN. Part of the organically-bound $\mathrm{S}$, however, may be volatised after its mineralisation by soil micro-organisms (Novák et al., 2000), which would reduce the time of S wash out. On the other hand, the S leaching rate may gradually decrease and $\mathrm{S}$ removal may last longer.

The thinner soil cover in alpine catchments (TM soils) accumulated smaller amounts of S compared to the forest sites in BF. Sulphur accumulation in TM soils represented only $\sim 10 \%$ of S deposited over the 1930-2000 period, while $\sim 90 \%$ of this load was leached (Table 3). TM soils had already become a net source of $\mathrm{SO}_{4}-\mathrm{S}$ in the late $1980 \mathrm{~s}$ with an average annual $\mathrm{SO}_{4}-\mathrm{S}$ leaching of 15 and $21 \mathrm{mmol} \mathrm{m}^{-2} \mathrm{yr}^{-1}$ (at WS and MO, respectively). The pool of water extractable $\mathrm{SO}_{4}-\mathrm{S}$ in TM soils was one order of magnitude lower than in BF soils (Table 3) and equalled approximately the average annual leaching of $\mathrm{SO}_{4}-\mathrm{S}$ from TM soils. Assuming $\mathrm{S}$ leaching from the total pool of $\mathrm{S}$, which accumulated in the soil over the 1930-2000 period, the time for $\mathrm{S}$ wash out is estimated as 10 years for MO and 20 years for WS at the present $\mathrm{S}$ deposition rate. The process of total wash out of anthropogenic $\mathrm{S}$, however, will probably last substantially longer in $\mathrm{TM}$ because $\mathrm{SO}_{4}-\mathrm{S}$ leaching decreased over the last decade, being 15-27 mmol m${ }^{-2} \mathrm{yr}^{-1}$ in 1991-1992 and $5-14 \mathrm{mmol} \mathrm{m}^{-2} \mathrm{yr}^{-1}$ in 2000 (Fig. 2D).

\section{NITROGEN}

Trends in emission and deposition rates of oxidised nitrogen forms

The emission rate of $\mathrm{NO}_{\mathrm{x}}$ increased relatively slowly between 1850 and 1950 (from 10 to $55 \mathrm{mmol} \mathrm{m}^{-2} \mathrm{yr}^{-1}$ ) and then by $\sim 4 \mathrm{mmol} \mathrm{m}^{-2} \mathrm{yr}^{-1}$ up to around $190 \mathrm{mmol} \mathrm{m}^{-2} \mathrm{yr}^{-1}$ in the 1980s (Fig. 3A). Since 1989, $\mathrm{NO}_{\mathrm{x}}$ emissions have decreased primarily due to optimisation of combustion regimes at the main stationary sources. The decrease in $\mathrm{NO}_{x}$ emissions was rapid $\left(\sim 17 \mathrm{mmol} \mathrm{m}^{-2} \mathrm{yr}^{-1}\right)$ up to 1994 , then less pronounced and by 1999 emissions were 88 $\mathrm{mmol} \mathrm{m}{ }^{-2} \mathrm{yr}^{-1}$. Available data on Central European emissions of $\mathrm{NO}_{\mathrm{x}}$ were similar to the CS emission trend (Fig. 3A).

Estimated long-term trends in wet-only and bulk deposition of $\mathrm{NO}_{3}$ in the Czech Republic and northern Slovakia (Fig. 3B) agree well with the measured data (wetonly, $\mathrm{P}<0.001$; bulk, $\mathrm{P}<0.05)$ and provide a reasonable background for estimation of throughfall and bulk deposition of $\mathrm{NO}_{3}$ in BF and TM (Figs. 3C and 3D). According to this estimation, $\mathrm{NO}_{3}$ deposition rapidly increased in both mountain areas between 1950 and 1980 and reached their maxima of $\sim 100$ and $\sim 35 \mathrm{mmol} \mathrm{m}^{-2} \mathrm{yr}^{-1}$ (throughfall in BF and bulk in TM, respectively) in the late 1980s. During the 1990s, $\mathrm{NO}_{3}$ deposition has decreased by 30-35\% and 1999 levels are comparable to the middle 1960s. 

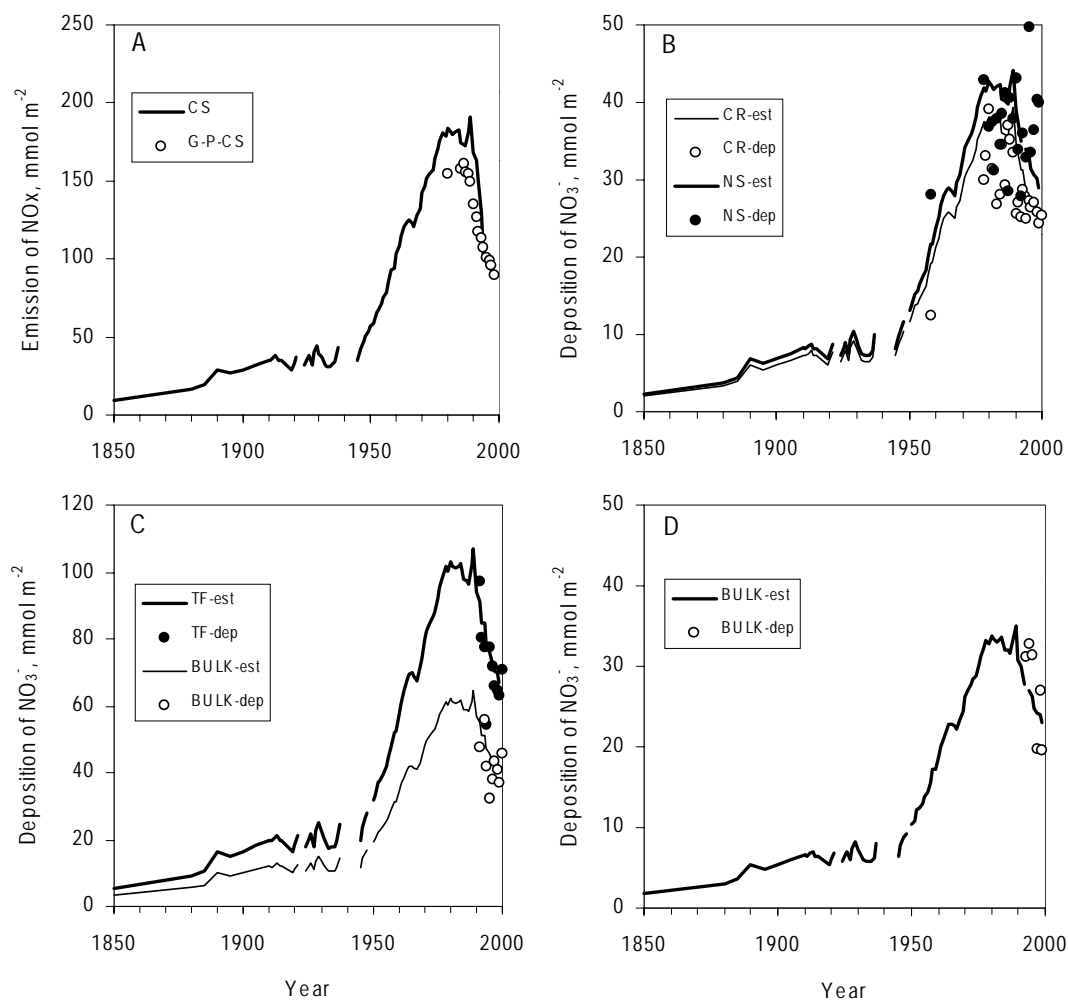

Fig. 3. Trends in emission and deposition rate of oxidised $N$ forms: (A) Emissions of $N O_{x}$ in the area of the Czech Republic and Slovakia (CS) and in Central Europe (Germany, Poland, Czech Republic and Slovakia, G-P-CS; Berge, 1997). (B) Comparison between estimated and measured wet-only and bulk deposition of $\mathrm{NO}_{3}-\mathrm{N}$ in the Czech Republic (CR) and northern Slovakia (NS), respectively. (C) Comparison between estimated and measured throughfall (TF) and bulk (BULK) deposition of $\mathrm{NO}_{3}-\mathrm{N}$ in the Bohemian Forest. (D) Comparison between estimated and measured bulk deposition of $\mathrm{NO}_{3}-\mathrm{N}$ in the Tatra Mountains. All data are based on annual basis.

Trends in emission and deposition rates of reduced nitrogen forms

The trend in emission rate of $\mathrm{NH}_{3}$ followed a different pattern to $\mathrm{SO}_{2}$ and $\mathrm{NO}_{x}$ emissions (Fig. 4A) being mostly derived from agricultural production. CS emissions of $\mathrm{NH}_{3}$ were on average 25\% lower than Central European emissions primarily due to the high emission rate of $\mathrm{NH}_{3}$ in Germany (Berge, 1997). Cattle and pig production contributed around $65 \%$ to $85 \%$ to the total anthropogenic $\mathrm{CS}$ emissions of $\mathrm{NH}_{3}$ over the whole 1850-2000 period. The emission rate of $\mathrm{NH}_{3}$ was already high $\left(\sim 40 \mathrm{mmol} \mathrm{m}^{-2} \mathrm{yr}^{-1}\right)$ in 1850 , increased only slightly between 1850 and 1920 due to increasing number of inhabitants, and was relatively stable in the 1920-1950 period $\left(\sim 55 \mathrm{mmol} \mathrm{m}^{-2} \mathrm{yr}^{-1}\right)$. Between 1950 and 1980, $\mathrm{NH}_{3}$ emissions increased by $\sim 1 \mathrm{mmol} \mathrm{m} \mathrm{m}^{-2} \mathrm{yr}^{-1}$ and levelled off at $88 \mathrm{mmol} \mathrm{m}^{-2} \mathrm{yr}^{-1}$ in the 1980s (Fig. 4A). Then, $\mathrm{NH}_{3}$ emissions decreased primarily due to a $55 \%$ reduction in cattle production and fertilisation of farmland. As with $\mathrm{NO}_{3}$, this decrease was more rapid in the 1990-1994 period than in the second half of the 1990s. In 1999, CS emissions of $\mathrm{NH}_{3}$ were comparable to the situation one century ago (Fig. 4A).
Estimated long-term trends in wet-only and bulk deposition of $\mathrm{NH}_{4}$ in the Czech Republic and northern Slovakia agree well $(\mathrm{P}<0.001)$ with the measured data (Fig. 4B) and provide a reasonable background for estimation of throughfall and bulk deposition of $\mathrm{NH}_{4}$ in $\mathrm{BF}$ and TM. According to this estimation (Figs. $4 \mathrm{C}$ and $4 \mathrm{D}$ ), $\mathrm{NH}_{4}$ deposition was relatively stable in both mountain areas between 1850 and 1950, being 34-45 $\mathrm{mmol} \mathrm{m}^{-2} \mathrm{yr}^{-1}$ in BF throughfall and 26-36 $\mathrm{mmol} \mathrm{m}^{-2} \mathrm{yr}^{-1}$ in TM bulk deposition. Then, $\mathrm{NH}_{4}$ deposition increased by $\sim 15 \mathrm{mmol} \mathrm{m}^{-2}$ in both mountain areas between 1950 and 1980, stabilised in the 1980 s and decreased $25-27 \%$ during the 1990s. Consequently, present $\mathrm{NH}_{4}$ deposition is comparable with levels in the 1900-1950 period in both areas (Figs. 4C and 4D).

\section{Fluxes and mass budget of nitrogen}

Trends in the atmospheric input of DIN and its output from catchment-lake ecosystems of BF and TM are shown in the upper part of Fig. 5. In both areas, DIN outputs were close to zero in the 1930 s, increased in parallel with DIN 

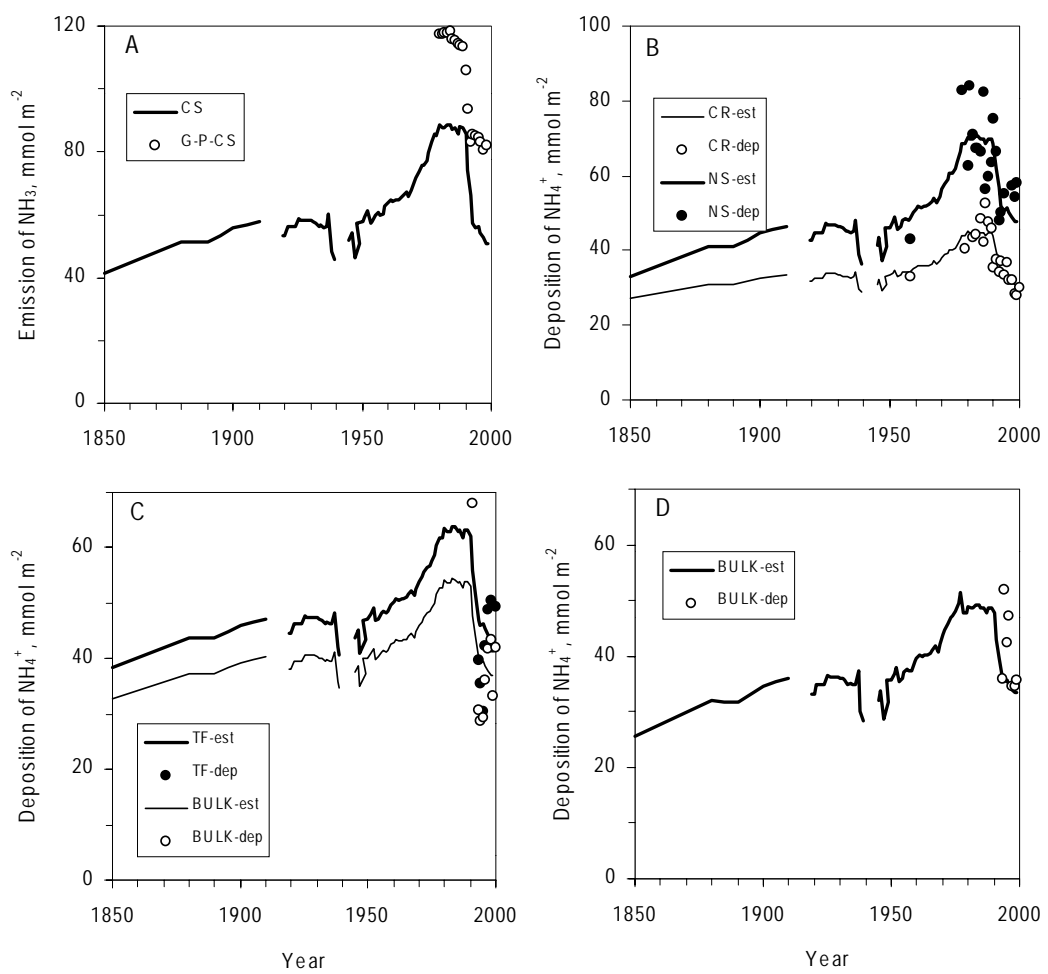

Fig. 4. Trends in emission and deposition rate of reduced $\mathrm{N}$ forms: (A) Emissions of $\mathrm{NH}_{3}$ in the area of the Czech Republic and Slovakia (CS) and in Central Europe (Germany, Poland, Czech Republic and Slovakia, G-P-CS; Berge, 1997). (B) Comparison between estimated and measured wet-only and bulk deposition of $\mathrm{NH}_{4}-\mathrm{N}$ in the Czech Republic (CR) and northern Slovakia $(\mathrm{NS})$, respectively. (C) Comparison between estimated and measured throughfall (TF) and bulk (BULK) deposition of $\mathrm{NH}_{4}-\mathrm{N}$ in the Bohemian Forest. (D) Comparison between estimated and measured bulk deposition of $\mathrm{NH}_{4}^{-} \mathrm{N}$ in the Tatra Mountains. All data are based on annual means.
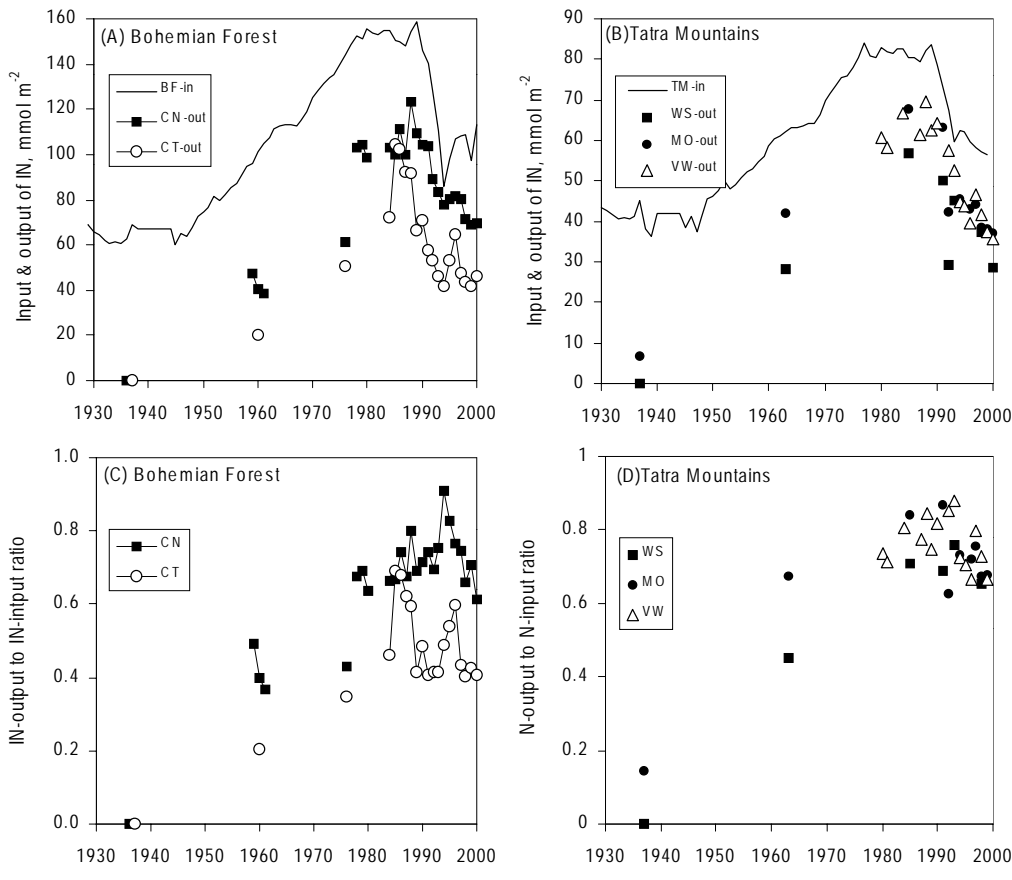

Fig. 5. Trends in fluxes of dissolved inorganic nitrogen $\left(\mathrm{DIN}=\mathrm{NH}_{4}-\mathrm{N}+\mathrm{NO}_{3}-\mathrm{N}\right)$. Upper part: Comparison of DIN input by atmospheric deposition in the Bohemian Forest (A) and Tatra Mountains (B) to the DIN output from catchment-lake ecosystems in the 1930-2000 period. Lower part (C, D): Ratio of

DIN output to DIN input. For lake codes see Table 1. All data are based on annual basis. 
deposition during the next four decades and reached a plateau in the 1980s. During the last decade, DIN outputs have decreased from all lakes. In contrast to $\mathrm{S}$, ratios of $\mathrm{N}$ output to $\mathrm{N}$-input $\left(\mathrm{N}_{\text {out }}: \mathrm{N}_{\text {in }}\right)$ paralleled the increase and decrease in deposition rate and did not exceed 1 in any lake after the deposition decline (lower part of Fig. 5). The estimated DIN fluxes reasonably reflect these trends, although the magnitude of the values is uncertain for two major reasons.

First, total deposition of DIN was probably higher than the estimated throughfall and bulk deposition given in Figs. 3-5. Throughfall DIN includes $\mathrm{N}$ derived from wet plus dry and cloud deposition less net $\mathrm{N}$ removal by canopy assimilation (e.g. Dise et al., 1998). The later process modifies significantly the composition of atmospheric deposition (Lovett, 1992). The average ratio between throughfall and bulk deposition of DIN was 1.3 in BF. Lovett (1992) has shown that total atmospheric deposition of DIN into forest sites generally exceeds bulk deposition by a factor of 1.2-1.9. Using the upper factor of 1.9 for $\mathrm{BF}$ (due to being in the vicinity of large $\mathrm{NO}_{x}$ emissions sources), the estimated throughfall deposition of DIN into this area was 35-40\% underestimated. Similarly, in TM, dry deposition was probably an important source of DIN. Lydersen et al. (1997) estimated dry deposition of oxidised and reduced $\mathrm{N}$ forms to be 7 and $12 \mathrm{mmol} \mathrm{m}^{-2} \mathrm{yr}^{-1}$ in 1996 in TM, which represented $25 \%$ of total DIN deposition.

Second, comparison between estimated fluxes and measured fluxes at CT provides evidence that DIN output from catchment-lake ecosystems was underestimated (Table 4). The 1998-2000 average output of DIN from CT was $35 \%$ higher than the estimated flux. This is due to the seasonality in $\mathrm{NO}_{3}$ concentrations in the lake outflow with minima during the vegetation growing season and maxima

Table 4. Comparison between DIN fluxes in the Certovo catchment-lake ecosystem (CT), estimated from Eqns. (1 and 2) and measured (Kopácek et al. 2000a; and unpubl. data). Data are averages for 1998-2000 period; units are $\mathrm{kmol} \mathrm{yr}^{-1}$

\begin{tabular}{lll}
\hline & estimated & measured \\
\hline$M_{\text {INPUT }}$ & 93.3 & 97.8 \\
$M_{\text {OUTPUT }}$ & 40.3 & 62.7 \\
$\Delta M_{\text {LAKE }}$ & $\mathrm{N}^{*}$ & -0.3 \\
$R_{\text {LAKE }}$ & 18.6 & 22.8 \\
$R_{\text {SOIL }}$ & 34.4 & 12.7 \\
${ }^{*} \mathrm{~N}$, neglected & & \\
\hline
\end{tabular}

in late winter. Historical $\mathrm{NO}_{3}$ concentrations on $\mathrm{BF}$ and $\mathrm{TM}$ lakes used in this study were mostly based on summer or early autumn observations and were lower than volume weighted mean concentrations. For example, in $\mathrm{CT}$ and $\mathrm{CN}$ lakes, volume weighted mean concentrations of $\mathrm{NO}_{3}$ were 12-44\% higher than autumn concentrations in the 1998 2000 period (e.g. in 2000, $56 v .39 \mu \mathrm{mol} \mathrm{l}^{-1}$ in CT and $64 v$. $57 \mu \mathrm{mol} 1^{-1}$ in $\mathrm{CN}$ ). Consequently, the $30-40 \%$ underestimation of DIN deposition was in part compensated by a similar underestimation of DIN output from the ecosystem which reduced the error in estimation of longterm retention of DIN in the soils.

In-lake retention of DIN was a significant component of $\mathrm{N}$ fluxes within the catchment-lake ecosystems. There was a good agreement between estimated and measured in-lake DIN retention for both CT (Table 4) and CN (42 and 53 $\mathrm{kmol} \mathrm{yr}^{-1}$, respectively). Another approach to estimating inlake retention of DIN was used based on the accumulation rate of $\mathrm{N}$ in sediments. Veselý at al. (1993) estimated a mass accumulation rate of $53 \mathrm{~g} \mathrm{~m}^{-2} \mathrm{yr}^{-1}$ in CT over the last century, while the average $\mathrm{N}$ content of the uppermost $(1-\mathrm{cm})$ layer was $2.4 \mathrm{mmol} \mathrm{g}^{-1}$ (Kopácek, unpubl. data) and the resulting $\mathrm{N}$ retention in sediments was $13 \mathrm{kmol} \mathrm{yr}^{-1}$. This estimate is in concordance with measured in-lake retention of DIN (Table 4), although somewhat lower because the measured in-lake $\mathrm{N}$ retention also includes $\mathrm{N}$ losses due to denitrification.

The cumulative atmospheric inputs of DIN in the 1930 2000 period surprisingly represented "only" $\sim 60 \%$ of cumulative DIN deposition from 1850 to 2000 (Table 5). The primary reason was high $\mathrm{NH}_{4}$ deposition throughout the whole period (Fig. 4). Between $30 \%$ to $60 \%$ of DIN inputs were leached from the catchments and 10-20\% were removed by in-lake processes. Cumulative outputs of DON were higher than inputs and represented an important proportion (26-38\%) of total $\mathrm{N}$ export from ecosystems (Table 5). The net $\mathrm{N}$ retention in BF soils based on Eqn. (1) was $20 \%$ and $40 \%$ of the $\mathrm{N}$ input (DIN plus DON) in $\mathrm{CN}$ and $\mathrm{CT}$ catchments, respectively, while the $\mathrm{N}$ budget for TM lakes indicates a similar relative retention $35 \%$ and $20 \%$ ) of $\mathrm{N}$ in alpine soils but at lower absolute values (Table $5)$.

The $\mathrm{N}$ concentrations of BF and TM soils in 2000 was more than an order of magnitude higher than $\mathrm{N}$ retention in soils over the 1930-2000 period (Table 5). Ratios of C:N averaged 22 and 24 in forest catchments and 18 in alpine catchments. At soil C:N ratios of 25 or less, there is a potential risk of elevated export of DIN from soils (Gundersen et al., 1998b). Hypothetical soil C : N ratios in the 1930s, estimated from the present soil composition, were slightly higher but already $\leq 25$ (Table 5 ). A relatively low 
Table 5. Cumulative budgets of $\mathrm{N}$ in the Bohemian Forest (CN and CT) and Tatra (WS and MO) catchment-lake ecosystems. Numbers in brackets represent relevant year and/or period. For lake codes see Table 1. All units are mol m${ }^{-2}$ except for C:N ratios $\left(\mathrm{mol} \mathrm{mol}^{-1}\right)$.

\begin{tabular}{|c|c|c|c|c|}
\hline & $C N$ & $C T$ & $W S$ & $M O$ \\
\hline Cumulative DIN deposition (1850-2000) & 11.5 & 11.6 & 6.9 & 6.9 \\
\hline Cumulative DIN input (1930-2000) & 7.4 & 7.5 & 4.2 & 4.2 \\
\hline Cumulative ON input (1930-2000) & 0.9 & 0.9 & 0.5 & 0.5 \\
\hline Cumulative DIN output (1930-2000) & 3.5 & 2.4 & 2.0 & 2.7 \\
\hline Cumulative ON output (1930-2000) & 1.3 & 1.5 & 0.7 & 0.7 \\
\hline In-lake retention of $\mathrm{N}(1930-2000)^{1)}$ & 1.7 & 1.1 & 0.4 & 0.4 \\
\hline Change in DIN content in lake water $(1930-2000)^{1)}$ & 0.13 & 0.08 & 0.05 & 0.04 \\
\hline $\mathrm{N}$ retention in soil (1930-2000) & 1.7 & 3.3 & 1.6 & 0.9 \\
\hline $\mathrm{N}$ content in soil $(2000)$ & 64.9 & 53.2 & 24.0 & 19.9 \\
\hline C content in soil (2000) & 1429 & 1263 & 437 & 362 \\
\hline $\mathrm{C}: \mathrm{N}$ in soil (2000) & 22 & 24 & 18 & 18 \\
\hline Hypothetical C:N in soil $(1930)^{2)}$ & 23 & 25 & 20 & 19 \\
\hline
\end{tabular}

hypothetical decrease in $\mathrm{C}: \mathrm{N}$ ratios of $\mathrm{BF}$ and $\mathrm{TM}$ soils fits well with conclusions made by Dise et al. (1998), which suggested that changes in soil $\mathrm{C}: \mathrm{N}$ ratios may be a longterm process. The low soil C:N ratios (already in the 1930s) indicate a limited capacity of both mountain areas to assimilate elevated atmospheric deposition of DIN, even at the beginning of the mass budget period.

\section{Response of forest and alpine ecosystems to DIN deposition}

Estimated throughfall deposition of DIN was stable in BF during the 1880-1950 period (between 53 and $75 \mathrm{mmol}$ $\mathrm{m}^{-2} \mathrm{yr}^{-1}$ ) (Figs. 3 and 4). The average value of $67 \mathrm{mmol}$ $\mathrm{m}^{-2} \mathrm{yr}^{-1}\left(9.5 \mathrm{~kg} \mathrm{ha}^{-1} \mathrm{yr}^{-1}\right)$ was close to the empirically derived threshold of $10 \mathrm{~kg} \mathrm{ha}^{-1} \mathrm{yr}^{-1}$ for European forest soils below which DIN leaching from soils was not expected to occur (e.g. Dise et al., 1998; Curtis et al., 1998). This outcome is supported by historical data from BF lakes where concentrations of $\mathrm{NO}_{3}$ were $<2 \mu \mathrm{mol} \mathrm{l}^{-1}$ in 1936 (Veselý and Majer, 1992), suggesting that nearly all DIN from throughfall deposition was removed by terrestrial and inlake processes. Estimated DIN retention in soils, calculated on an annual basis from Eqn. (1), show that $\mathrm{CN}$ and $\mathrm{CT}$ catchments could assimilate high DIN deposition (50 and $60 \mathrm{mmol} \mathrm{m}^{-2} \mathrm{yr}^{-1}$, respectively) during the $1930-1970$ period. However, DIN retention in BF soils has declined in the last two decades, varying between $0-60 \mathrm{mmol} \mathrm{m} \mathrm{m}^{-2} \mathrm{yr}^{-1}$ in CT, and being close to zero or even negative (since the late 1980s) in CN catchment. Thus, soils in CN catchment have probably become a net source of DIN (practically all as $\mathrm{NO}_{3}$ ) since the second half of the 1980s. The $\mathrm{N}_{\text {out }}: \mathrm{N}_{\text {in }}$ ratios for the whole $\mathrm{CN}$ catchment-lake ecosystem has remained $<1$ (Fig. 5) mainly because of the elevated in-lake retention of $\mathrm{N}$ which increases as a function of $\mathrm{N}$ loading (Kelly et al., 1987).

Estimated bulk deposition of DIN varied between 35 and $45 \mathrm{mmol} \mathrm{m}^{-2} \mathrm{yr}^{-1}$ (average of $41 \mathrm{mmol} \mathrm{m}^{-2} \mathrm{yr}^{-1}$, i.e. $\sim 6 \mathrm{~kg}$ $\mathrm{ha}^{-1} \mathrm{yr}^{-1}$ ) in TM during the 1880-1950 period (Figs. 3 and 4). In 1937, Stangenberg (1938) found $\mathrm{NO}_{3}$ concentrations between $0-4 \mu \mathrm{mol} \mathrm{l}^{-1}$ in $16 \mathrm{TM}$ lakes. This low DIN leaching suggested steady-state conditions within the catchment-lake ecosystem. As the in-lake retention of DIN was lower at that time, due to low DIN concentrations, most DIN input was probably retained in the soils. In the 1980-2000 period, estimated retention of DIN in alpine soils decreased to 10$20 \mathrm{mmol} \mathrm{m}^{-2} \mathrm{yr}^{-1}$ in MO and WS catchments. In contrast, the ability of VW catchment to assimilate DIN was negligible and estimated DIN retention varied between -9 and $7 \mathrm{mmol} \mathrm{m}^{-2} \mathrm{yr}^{-1}$ in the 1980-2000 period. Such results can be expected in VW catchment, where soil cover is sparse (Table 1). These sparse moraine soils with low $\mathrm{C}: \mathrm{N}$ ratios (18) probably only adsorb and nitrify deposited $\mathrm{NH}_{4}$ but 


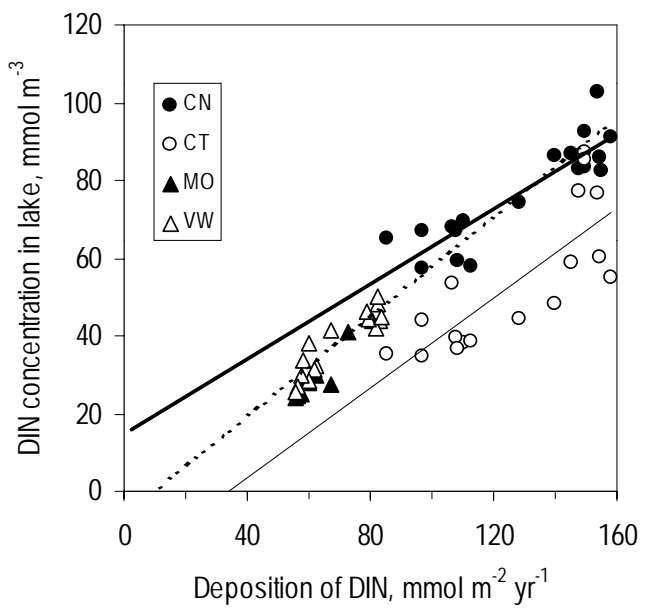

Fig. 6. Relationship between DIN deposition (throughfall for $C N$ and $C T$ and bulk for MO and VW lakes) and concentrations of DIN in the Bohemian Forest and Tatra lakes in the 1980-2000 period. Equations of linear regressions: $C N, y=0.5 x+15 ; C T, y=0.6 x-$ 19; $M O, y=0.8 x-20 ; V W, y=0.7 x-7 ; P<0.001$ for allregressions. For lake codes see Table 1.

are not able to accumulate $\mathrm{N}$. This fact may explain negligible $\mathrm{NH}_{4}$ but high $\mathrm{NO}_{3}$ concentrations (roughly equal to DIN concentration in precipitation), which were found in VW and some other TM lakes with rocky catchments (Kopácek et al., 2000b).

The present DIN export from both BF and TM ecosystems fits well with the empirical models which link DIN leaching to current $\mathrm{N}$ deposition, soil $\mathrm{pH}$ or $\mathrm{C}: \mathrm{N}$ ratios (Dise et al., 1998; Gundersen et al., 1998b), as well as to the ratios of DOC to dissolved DON in water (Harriman et al., 1998). The decreasing trends in retention of DIN within both BF and TM soils suggest, however, that these dose-response functions may change over time. The historical change in composition of atmospheric deposition might partly contribute to the lower $\mathrm{N}$ retention within $\mathrm{BF}$ and $\mathrm{TM}$ ecosystems. Dise et al. (1998) have reported increasing $\mathrm{N}$ retention with increasing proportion of $\mathrm{NH}_{4}$ in deposition. The $\mathrm{NH}_{4}$ to $\mathrm{NO}_{3}$ ratio in $\mathrm{BF}$ and TM bulk deposition is estimated to have decreased four-fold between the 1930s and 1990s (Figs. 3 and 4). Furthermore, increasing N deposition may induce changes in vegetation communities leading to changes in $\mathrm{N}$ leaching. Differences in vegetation status may also explain some inter-site variation in $\mathrm{N}$ export from BF and TM lakes (Kopácek et al., 2001). None of these factors, however, can explain the different abilities of geographically adjacent catchments, $\mathrm{CN}$ and $\mathrm{CT}$, to accumulate and export $\mathrm{N}$ (Table 5). Clearly, other mechanisms are affecting the ability of ecosystems to immobilise $\mathrm{N}$, some of which may change during the period of elevated $\mathrm{N}$ deposition. An example of such changes has been observed in the mineralisation rate of soil organic matter (Gundersen et al., 1998a). In the BF lake catchments, Anderson et al. (2000) observed the highest rates of nitrification in the $\mathrm{CN}$ catchment. However, the reason is not clear and the processes involved require further study.

Despite these differences in the ability of catchments to retain N, DIN concentrations and transport from lakes generally decreased in parallel with decreasing deposition rate (Figs. 5 and 6). A similar pattern was observed in artificial manipulation experiments, when $\mathrm{NO}_{3}$ leaching responded promptly to changes in $\mathrm{N}$ input (Gundersen et al., 1998a). Consequently, N-saturation of BF and TM ecosystems seems to be reversible although the extent of change is difficult to predict. Linear regressions between DIN input and in-lake concentrations of DIN in the 19802000 period (Fig. 6) provide a rough estimate of critical levels of DIN deposition at which negligible concentrations of DIN were likely to leach. Critical DIN deposition of 32 and $25 \mathrm{mmol} \mathrm{m}^{-2} \mathrm{yr}^{-1}$ (i.e. $\sim 4 \mathrm{~kg} \mathrm{ha}^{-1}$ ) were estimated for CT and MO, respectively, which is $<50 \%$ of the steady-state DIN deposition in the 1930s. By comparison, the predominantly rocky catchment of VW with undeveloped moraine soils will only be able to assimilate a maximum 10 mmol m${ }^{-2} \mathrm{yr}^{-1}$ of DIN deposition. The worst situation, in terms of ecosystem recovery from $\mathrm{N}$-saturation, can be expected in $\mathrm{CN}$ which currently shows a net terrestrial loss of $\mathrm{NO}_{3}$. Even if DIN deposition falls to zero, DIN concentrations in $\mathrm{CN}$ would be $\sim 15 \mu \mathrm{mol} \mathrm{l}^{-1}$, although this may be an overestimate if steady-state is reached.

\section{Conclusions}

Negligible ecosystem outputs of S and DIN from BF and TM catchment-lake ecosystems in the 1930s suggested an equilibrium between deposition and retention. This equilibrium reflected relatively stable $S$ and DIN emissions over previous decades. Then, the rapid increases of $\mathrm{S}$ and DIN deposition resulted in pronounced changes in the chemistry of both terrestrial and aquatic parts of these ecosystems. Sulphur accumulation in soils partly mitigated the increase in lake water $\mathrm{SO}_{4}$ during the $1930-1990$ period, however, soil desorption has recently become an important source of $\mathrm{SO}_{4}$ for surface waters in both $\mathrm{BF}$ and TM after the respective $80 \%$ and $50 \%$ decline in $\mathrm{S}$ deposition. The new steady-state conditions in $\mathrm{S}$ dose and export will be reached sooner in the alpine than in forest ecosystems due to the lower amount of $\mathrm{S}$ accumulated in soils.

Lake water concentrations of $\mathrm{NO}_{3}$ generally followed the increasing, as well as decreasing, DIN deposition trends in both areas. Nitrogen saturation of these ecosystems seems to reflect DIN dose and is largely reversible despite the complexity of the N-biogeochemical cycle. The ability of 
terrestrial ecosystems to assimilate DIN deposition, however, declined between 1930 and 2000 (CT, WS, and $\mathrm{MO})$ and/or completely changed from $\mathrm{N}$ retention to $\mathrm{N}$ production $(\mathrm{CN})$.

Using the status of BF and TM lakes in the 1930s as a measure of "unaffected" Central European mountainous ecosystems, the threshold levels of $\mathrm{S}$ and $\mathrm{N}$ emissions, which should be reached to enable recovery from acidification and $\mathrm{N}$-saturation can be estimated. The present Central European emission rates of $\mathrm{S}$ have nearly declined to the required threshold level $\left(<60 \mathrm{mmol} \mathrm{m}^{-2} \mathrm{yr}^{-1}\right)$ and future soil and water acidification due to $\mathrm{SO}_{4}$ leaching will result primarily from leaching of $\mathrm{S}$ accumulated in soils. To reach the DIN deposition of the 1930s, the recent Central European emissions of DIN should be reduced to $<80 \mathrm{mmol} \mathrm{m}^{-2} \mathrm{yr}^{-1}$. Even such a large reduction, however, will probably not be sufficient for the complete recovery of the ecosystems from $\mathrm{N}$-saturation due to changes in their ability to retain $\mathrm{N}$.

\section{Acknowledgements}

We thank M. Dvoøáková and M. Mitošinková from the Czech and Slovak Hydrometeorological Institutes, respectively, for data on atmospheric deposition in the Czech Republic and Slovakia, and Ron Harriman from Freshwater Fisheries Laboratory, Pitlochry, Scotland, for useful comments and language improvements. This study was partly supported by the Grant Agency of the Czech Republic (project No 206/00/0063), and the Commission of the European Community as part of the RECOVER:2010 (Project No. EVK1-CT-1999-00018) and EMERGE (EVK1-CT-1999-00032) projects.

\section{References}

Aber, J.D., McDowell, W., Nadelhoffer, K.J., Magill, A., Berntson, G., Marnakea, M., McNulty, S., Currie, W., Rustad, L. and Fernandez, I., 1998. Nitrogen saturation in temperate forest ecosystems: hypotheses revisited. BioScience, 48, 921-934.

Alewell, C., 1998. Investigating sulphate sorption and desorption of acid forest soils with special consideration of soil structure. Z. Pflanzenernähr. Bodenk., 161, 73-80.

Alewell, C., Manderscheid, B., Meesenburg, H. and Bittersohl, J., 2000. Is acidification still an ecological threat? Nature, 407, $856-857$.

Anderson, I.C., Tobias, C.R., Macko, S.A. and Poth, M.A., 2000. Sources and sinks of nitrogen in acidified glacial lakes of the Bohemian Forest, Czech Republic. Silva Gabreta, 4, 135-146.

Asman, W.A.H., Drukker, B. and Janssen, A.J., 1988. Modelled historical concentrations and depositions of ammonia and ammonium in Europe. Atmos. Environ., 22, 725-735.

Berge, E., 1997. Transboundary air pollution in Europe, Part 1. EMEP MSC-W Report 1/97, Norwegian Meteorological Institute, Oslo, $108 \mathrm{pp}$.
Bombówna, M., 1965. Hydrochemical investigations of the Morskie Oko lake and the Czarny staw lake above the Morskie Oko in the Tatra Mountains. In: Limnological Investigations in the Tatra Mountains and Dunajec River Basin, K. Starmach (Ed.), 7-11. Zeszyt No 11, Komitet Zagospodarzovania Ziem Górskych, Polish Academy of Sciences, Kraków.

Bombówna, M. and Wojtan, K., 1996. Temporal changes in the water chemistry of the Tatra lakes. In: Przyroda Tatrzanskiego Parku Narodovego a Czlowiek, Tom 3, Wplyw czlowieka, Z. Krzan (Ed.), 56-59. TPN, Kraków-Zakopane, Poland (in Polish).

Buijsman, E., Maas, H.F.M. and Asman, W.A.H., 1987. Anthropogenic $\mathrm{NH}_{3}$ emissions in Europe. Atmos. Environ., 21, 1009-1022.

Curtis, C.J., Allott, T.E.H., Reynolds, B. and Harriman, R., 1998. The prediction of nitrate leaching with the first-order acidity balance (FAB) model for upland catchment in Great Britain. Water Air Soil Pollut., 105, 205-215.

Dise, N.B. and Wright, R.F., 1995. Nitrogen leaching from European forests in relation to nitrogen deposition. Forest Ecol. Manage., 71, 153-161.

Dise, N.B., Matzer, E. and Gundersen, P., 1998. Synthesis of nitrogen pools and fluxes from European forest ecosystems. Water Air Soil Pollut., 105, 143-154.

Evans, C.D., Cullen, J.M., Alewell, C., Kopácek, J., Marchetto, A., Moldan, F., Prechtel, A., Rogora, M., Veselý, J. and Wright, R.F., 2001. Recovery from acidification in European surface waters. Hydrol. Earth Syst. Sci., 5, 283-297.

Galloway, J.N., Charlson, R.J., Andreae, M.O. and Rodbe, H., 1985. The Biogeochemical Cycling of Sulfur and Nitrogen in the Remote Atmosphere. Reidel, Boston, USA, 249 pp.

Gundersen, P., Emmett, B.A., Kjonaas, O.J., Koopmans, C.J. and Tietema, A., 1998a. Impact of nitrogen deposition on nitrogen cycling in forests: a synthesis of NITREX data. Forest Ecol. Manage., 71, 143-151.

Gundersen, P., Callesen, I. and de Vries, W., 1998b. Nitrate leaching in forest ecosystems is related to forest floor $\mathrm{C} / \mathrm{N}$ ratios. Environ. Pollut., 102, 403-407.

Harriman, R., Curtis, C. and Edwards, A.C., 1998. An empirical approach for assessing the relationship between nitrogen deposition and nitrate leaching from upland catchments in the United Kingdom using runoff chemistry. Water Air Soil Pollut., 105, 193-203.

Henriksen, A., Mill, W.A., Kot, M., Rzychon , D. and Wathne, B., 1992. Critical loads of acidity to surface waters: A case study from the Polish Tatra Mountains. Report 29/1992, NIVA, Oslo, $34 \mathrm{pp}$.

Hruška, J., Kopácek, J., Hlavatý, T. and Hošek, J., 2000. Trend of atmospheric deposition of acidifying compounds at Certovo Lake, south-western Czech Republic (1992-1999). Silva Gabreta, 4, 71-86.

Hultberg, H., Moldan, F., Anderson, B.I. and Skeffington, R., 1998. Recovery from acidification in the forested covered catchment experiment at Gardsjön: Effects on Biogeochemical output fluxes and concentrations. In: Experimental Reversal of Acid Rain Effects. The Gardsjön Roof Project, H. Hultberg and R. Skeffington (Eds.), 157-184. Wiley, Chichester, UK.

Jírovec, O. and Jírovcová, M., 1937. Chemistry of the Bohemian Forest lakes. Vìstník k. c. spol. nauk, Tr. II (13), 1-21 (in Czech).

Kelly, C.A., Rudd, J.W.M., Hesslein, R.H, Schindler, D.W., Dillon, P.J., Driscoll, C.T., Gherini, S.A. and Hecky, R.E., 1987. Prediction of biological acid neutralisation in acid-sensitive lakes. Biogeochemistry, 3, 129-140.

Kopácek, J., and Stuchlík, E., 1994. Chemical characteristics of lakes in the High Tatra Mountains, Czechoslovakia. Hydrobiologia, 274, 49-56. 
Kopácek, J., Procházková, L., Stuchlík, E. and Blazka, P., 1995. The nitrogen-phosphorus relationship in mountain lakes: Influence of atmospheric input, watershed, and pH. Limnol. Oceanogr., 40, 930-937.

Kopácek, J., Procházková, L., Hejzlar, J. and Blazka, P., 1997. Trends and seasonal patterns of bulk deposition of nutrients in the Czech Republic. Atmos. Environ., 31, 797-808.

Kopácek, J., Hejzlar, J., Stuchlík, E., Fott, J. and Veselý, J., 1998. Reversibility of acidification of mountain lakes after reduction in nitrogen and sulphur emissions in Central Europe. Limnol. Oceanogr., 43, 357-361.

Kopácek, J., Hejzlar, J. and Porcal, P., 2000a. Mass balance of major ions in the Certovo watershed-lake ecosystem the 1998 hydrological year. Silva Gabreta, 4, 117-133.

Kopácek, J., Stuchlík, E., Straškrabová, V. and Pšenáková, P., $2000 \mathrm{~b}$. Factors governing nutrient status of mountain lakes in the Tatra Mountains. Freshwater Biol., 43, 369-383.

Kopácek, J., Stuchlík, E., Veselý, J., Schaumburg, J., Anderson, I.C., Fott, J., Hejzlar, J. and Vrba, J., 2001. Hysteresis in reversal of Central European mountain lakes from atmospheric acidification. Water Air Soil Pollut., (in press).

Lajczak, A., 1996. Hydrologia. In: Przyroda Tatrzañskiego Parku Narodowego, Z. Mirek, Z. Glowaciñski, K. Klimek and H. Piêkoœ-Mirkowa H. (Eds.), 169-196. Tatrzañski Park Narodowy, Zakopane-Kraków, (in Polish).

Lovett, G.M., 1992. Atmospheric deposition and canopy interactions of nitrogen. In: Atmospheric Deposition and Forest Nutrient Cycling. Ecological Studies 91., D.W. Johnson and S.E. Lindberg (Eds.), 152-166. Springer, New York.

Lydersen, E., Rzychon, D., Worsztynowicz, A., Torseth, K., Hanssen, J.E., Mill, W.A., Kot, M., Henriksen, A. and Wathne, B.M., 1997. Critical loads of acidity to lakes in the Polish Tatra Mountains-Final report. Report 44/1997, NIVA, Oslo, 49 pp.

Mackù, M., Podzimek, J. and Šrámek, L., 1959. Results of chemical analyses of precipitation collected on territory of Czechoslovak Republic in IGY. Geofysikální Sborník, 124, 441519.

Mylona, S., 1993. Trends of sulphur dioxide emissions, air concentrations and depositions of sulphur in Europe since 1880. EMEP/MSC-W Report 2/93, Norwegian Meteorological Institute, Oslo, $35 \mathrm{pp}$.

Nordstrom, D.K., 1982. The effect of sulphate on aluminium concentrations in natural waters: some stability relations in the system $\mathrm{Al}_{2} \mathrm{O}_{3}-\mathrm{SO}_{3}-\mathrm{H}_{2} \mathrm{O}$ at $298 \mathrm{~K}$. Geochim. Cosmochim. Acta, 46, 681-692.

Novák, M., Bottrell, S.H., Fottová, D., Buzek, F., Groscheová, H. and Zák, K., 1996. Sulphur isotope signals in forest soils of Central Europe along an air pollution gradient. Environ. Sci. Technol., 30, 3473-3476.

Novák, M., Kirkner, J.W., Groscheová, H., Havel, M., Cerný, J., Krejcí, R. and Buzek, F., 2000. Sulphur isotope dynamics in two Central European watersheds affected by high atmospheric deposition of SO. Geochim. Cosmochim. Acta, 64, 367-383.

Pacyna, J.M., Larssen, S. and Semb, A., 1991. European survey for $\mathrm{NO}_{\mathrm{x}}$ emissions with emphasis on Eastern Europe. Atmos. Environ., 25A, 425-439.

Prechtel, A., Alewell, C., Armbruster, M., Bittersohl, J., Cullen, J.M., Evans, C.D., Helliwell, R., Kopácek, J., Marchetto, A., Matzner, E., Meesenburg, H., Moldan, F., Moritz, K., Veselý, J. and Wright, R.F., 2001. Response of sulphur dynamics in European catchments to decreasing sulphate deposition. Hydrol. Earth Syst. Sci., 5, 311-325.

Procházková, L., 1960. Einfluss der Nitrate und Nitrite auf die Bestimmung des organischen Stickstoffs und Ammonimus im Wasser. Archiv für Hydrobiologie, 56, 179-185.
Procházková, L. and Blazka, P., 1999. Chemistry and biology of the Bohemian Forest lakes in the early 1960s. Silva Gabreta, 3, 65-72 (in Czech).

Stangenberg, M., 1938. Zur Hydrochemie der Tatraseen. Verhandlungen der internationalen Vereinigung für theoretische und angewandte Limnologie, 8, 211-220.

Stoddard, J.L., Jeffries, D.S., Lükewille, A., Clair, T.A., Dillon, P.J., Driscoll, C.T., Forsius, M., Johannessen, M., Kahl, J.S., Kellogg, J.H., Kemp, A., Mannio, J., Monteith, D.T., Murdoch, P.S., Patrick, S., Rebsdorf, A., Skjelkvale, B.L., Stainton, M.P., Traaen, T., van Dam, H., Webster, K.E., Wieting, J. and Wilander, A., 1999. Regional trends in aquatic recovery from acidification in North America and Europe. Nature, 401, 575578.

The MOLAR Chemistry Group, 1999. The MOLAR project: atmospheric deposition and lake water chemistry. J. Limnol., 58, 88-106.

Torssander, P. and Mörth, C.-M., 1998. Sulphur dynamics in the Roof experiment at Lake Gardsjön deduced from sulphur and oxygen isotope ratios in sulphate. In: Experimental Reversal of Acid Rain Effects. The Gardsjön Roof Project , H. Hultberg and R. Skeffington (Eds.), 185-206. Wiley, Chichester, UK.

Várhelyi, G., 1985. Continental and global sulphur budgets - I. Anthropogenic $\mathrm{SO}_{2}$ emissions. Atmos. Environ., 19, 1029-1040.

Veselý, J., 1994. Investigation of the nature of the Šumava lakes: a review. Casopis Národního Muzea, Praha, Øada pфírodovidná, 163, 103-120.

Veselý, J. and Majer, V., 1992. The major importance of nitrate increase for the acidification of two lakes in Bohemia. Doc. Ist. Ital. Idrobiol., 32, 83-92.

Veselý, J., Almquist-Jacobson, H., Miller, L.M., Norton, S.A., Appleby, P., Dixit, A.S. and Smol, J.P., 1993. The history and impact of air pollution at Certovo Lake, southwestern Czech Republic. J. Paleolimnol., 8, 211-231.

Veselý, J., Hruška, J., Norton, S.A. and Johnson, C.E., 1998. Trends in water chemistry of acidified Bohemian lakes from 1984 to 1995: I. Major solutes. Water Air Soil Pollut., 108, 107127.

Williams, M.W., Bales, R.C., Brown, A.D. and Melack, J.M., 1995. Fluxes and transformations of nitrogen in a high-elevation catchment, Sierra Nevada. Biogeochemistry, 28, 1-31.

Wright, R.F. and Hauhs, M., 1991. Reversibility of acidification: soils and surface waters. Proc. Roy. Soc. Edinburgh, 97B, 169191.

Wright, R.F., Lotse, E. and Semb, A., 1993. RAIN project: results after 8 years of experimentally reduced acid deposition to a whole catchment. Can. J. Fisheries Aquat. Sci., 50, 258-268.

\section{Appendix 1}

Trends in emissions of sulphur and nitrogen compounds The historical Czech and Slovak (CS) emission trends for $\mathrm{SO}_{2}$ and $\mathrm{NO}_{\mathrm{x}}$ were reconstructed using data from Yearbooks of the Czech and Slovak Statistical Offices for the 1980 1999 period and calculated data (1850-1980 period). Anthropogenic emissions of $\mathrm{SO}_{2}$ were calculated according to Várhelyi (1985) on the basis of fuel consumption (burning of brown and hard coal, oil, and wood). Historical trends in the average $\mathrm{S}$ content of coal and $\mathrm{S}$ retention in ash were obtained from Mylona (1993). Production of $\mathrm{SO}_{2}$ from 
smelting of sulphidic ores, which was an important source of $\mathrm{S}$ emission in the Czech Republic and Slovakia before 1900, was estimated by Holub (pers. comm.). When compared to the statistical yearbook data, the calculated data on anthropogenic $\mathrm{SO}_{2}$ emissions were on average $8 \%$ higher in the 1980-1990 period. Emissions of $\mathrm{SO}_{2}$ from natural sources were assumed to be $9 \mathrm{mmol} \mathrm{m}{ }^{-2} \mathrm{yr}^{-1}$ (non-sea salt $\mathrm{S}$ deposition in remote continental areas; Galloway et al., 1985) throughout the 1850-2000 period.

Anthropogenic emissions of $\mathrm{NO}_{x}$ were calculated according to Pacyna et al. (1991) on the basis of fuel consumption (lignite and hard coal, oil, gas, and wood) in stable and mobile sources. Emissions of $\mathrm{NO}_{\mathrm{x}}$ from natural sources (soil processes, burning of straw and stubble) in Europe were estimated as 3\% of anthropogenic emission in the 1980s (Pacyna et al., 1991). Applying this approach, the natural $\mathrm{NO}_{x}$ production in the Czech Republic and Slovakia was estimated as $\sim 5 \mathrm{mmol} \mathrm{m} \mathrm{mrr}^{-2}$ and was assumed to be constant throughout the $1850-2000$ period. The difference between the calculated total emission rate of $\mathrm{NO}_{x}$ and statistical yearbook data varied from $-6 \%$ to $6 \%$ in the 1980-1990 period.

The historical Czech and Slovak emission trends for $\mathrm{NH}_{3}$ were calculated for the whole 1850-2000 period according to Asman et al. (1988) from data on livestock production (cattle, pigs, sheep, goats, horses and poultry) and nitrogenous fertiliser production and consumption. Emissions of $\mathrm{NH}_{3}$ from natural sources $\left(\sim 9 \mathrm{mmol} \mathrm{m}^{-2} \mathrm{yr}^{-1}\right)$ was roughly estimated according to Buijsman et al. (1987) as $\sim 12 \%$ of anthropogenic emissions in Europe in the 1980s and was assumed to be constant throughout the 1850-2000 period. The difference between the calculated total emission rate of $\mathrm{NH}_{3}$ and statistical yearbooks data varied from $-14 \%$ to $3 \%$ in the $1985-1999$ period, with the average of $-5 \%$.

Data on Central European (Germany, Poland, Czech Republic, and Slovakia) emissions of $\mathrm{SO}_{2}, \mathrm{NO}_{x}$, and $\mathrm{NH}_{3}$ after 1980 came from Berge (1997) and Yearbooks of the National Statistical Offices. The historical trend for Central European emissions of $\mathrm{SO}_{2}$ before 1980 came from Mylona (1993).

\section{Appendix 2}

\section{Estimated trends in deposition of sulphur and nitrogen compounds}

Data on atmospheric deposition of $\mathrm{SO}_{4}, \mathrm{NO}_{3}$, and $\mathrm{NH}_{4}$ came from the following sources: (1) Wet-only deposition in the Czech Republic (CR), based on data from stations
Svratouch, Košetice, and Hradec Králové (Mackù et al., 1959, and the Czech Hydrometeorological Institute, 19782000 period). (2) Bulk deposition in northern Slovakia (NS) from the Chopok station, situated at $2008 \mathrm{~m}$ a.s.1. $40 \mathrm{~km}$ south-west of TM (Mackù et al., 1959, and the Slovak Hydrometeorological Institute, 1978-1999 period). (3) Atmospheric deposition in BF in the 1992-2000 period, based on one bulk and two throughfall sites differing in altitude (Hruška et al., 2000). (4) Bulk deposition in TM, measured at Starolesnianske Lake (southern part; $2000 \mathrm{~m}$ a.s.l.) in the 1997-1999 period (Stuchlík, unpubl. data) and at Hala Gasienicowa (northern part; $1520 \mathrm{~m}$ a.s.l.) in the 1993-1998 period (Lydersen et al., 1997, The MOLAR Chemistry Group, 1999).

Relationships used for estimation of $\mathrm{SO}_{4}, \mathrm{NH}_{4}$, and $\mathrm{NO}_{3}$ deposition in CR (wet-only) and NS (bulk) from the respective CS emissions of $\mathrm{SO}_{2}, \mathrm{NH}_{3}$ and $\mathrm{NO}_{\mathrm{x}}$ were as follows: (1) $\mathrm{SO}_{4}$ in $\mathrm{CR}$ : linear regression between measured $\mathrm{SO}_{4}$ deposition in $\mathrm{CR}$ and $\mathrm{CS}$ emissions of $\mathrm{SO}_{2}(\mathrm{P}<0.001)$. (2) $\mathrm{NH}_{4}$ in CR: linear regression between measured $\mathrm{NH}_{4}$ deposition in $\mathrm{CR}$ and $\mathrm{CS}$ emissions of $\mathrm{NH}_{3}(\mathrm{P}<0.001)$. (3) $\mathrm{NO}_{3}$ in $\mathrm{CR}$ : ratio of $0.21 \pm 0.03$ (average \pm standard deviation) between measured deposition of $\mathrm{NO}_{3}$ in $\mathrm{CR}$ and $\mathrm{CS}$ emissions of $\mathrm{NO}_{x}$. (4) $\mathrm{SO}_{4}$ in NS: linear regression between measured $\mathrm{SO}_{4}$ deposition at Chopok and CS emissions of $\mathrm{SO}_{2}(\mathrm{P}<0.01)$. (5) $\mathrm{NH}_{4}$ in NS: linear regression between measured $\mathrm{NH}_{4}$ deposition at Chopok and CS emissions of $\mathrm{NH}_{3}(\mathrm{P}<0.01)$. (6) $\mathrm{NO}_{3}$ in NS: ratio of $0.23 \pm 0.08$ between measured deposition of $\mathrm{NO}_{3}$ at Chopok and CS emissions of $\mathrm{NO}_{\mathrm{x}}$.

Estimation of $\mathrm{SO}_{4}, \mathrm{NH}_{4}$ and $\mathrm{NO}_{3}$ deposition in the Bohemian Forest (BF) and Tatra Mountains (TM) were based on estimated trends in their deposition in CR and NS, respectively, using the following ratios: (1) Measured throughfall deposition in BF to measured wet-only deposition in CR: $\mathrm{SO}_{4}, 4.5 \pm 0.8$ and $1.6 \pm 0.4$ for the period of CS emission higher and lower than $100 \mathrm{mmol} \mathrm{m}^{-2} \mathrm{yr}^{-2}$, respectively; $\mathrm{NH}_{4}, 1.4 \pm 0.3$; and $\mathrm{NO}_{3}, 2.7 \pm 0.5$. (2) Measured bulk deposition in $\mathrm{BF}$ to measured wet-only deposition in $\mathrm{CR}: \mathrm{SO}_{4}, 1.2 \pm 0.3 ; \mathrm{NH}_{4}, 1.2 \pm 0.3$; and $\mathrm{NO}_{3}, 1.6 \pm 0.2$. (3) Measured bulk deposition in TM to measured bulk deposition in NS (Chopok): $\mathrm{SO}_{4}, 0.9 \pm 0.3 ; \mathrm{NH}_{4}, 0.7 \pm 0.1$; and $\mathrm{NO}_{3}, 0.8 \pm 0.2$. The ratios were calculated for all available paired data and arithmetic means were used in the above calculations. Uncertainty associated with the deposition estimates was estimated as coefficient of variation of the mean, i.e. $< \pm 30 \%$. 
